\title{
From Iberia to the Southern Levant: The Movement of Silver Across the Mediterranean in the Early Iron Age
}

\author{
Jonathan R. Wood ${ }^{1} \mathbb{D} \cdot$ Ignacio Montero-Ruiz $^{2} \cdot$ Marcos Martinón-Torres $^{1}$
}

Published online: 22 January 2019

(C) The Author(s) 2019

\begin{abstract}
The origins of the silver trade across the Mediterranean, and the role of the Phoenicians in this phenomenon, remain contentious. This is partly because of difficulties encountered when trying to assign archaeological silver to its geological sources. Here we present a reanalysis of Iron Age silver hoards in the southern Levant, which demonstrates not only that recycling of silver was widespread in the Early and Late Iron Age, but that the components of this mixed silver originated from the Aegean, Anatolia and the western Mediterranean. An assessment of lead isotope analyses combined with compositional data allows the identification of mixing lines based on gold levels in the silver and the $\mathrm{Pb}$ crustal age (or, more loosely, geological age) of the ore from which the silver originated. It is shown that, from as early as the 11th century BC, these mixed silver signatures derive from the Taurus mountains in Anatolia, from Iberia and an unknown source-with Sardinia as an additional possibility-and Laurion in Greece in the Late Iron Age. In contrast to copper, which was deliberately alloyed with silver, gold appears to have been mixed unintentionally, through the melting down of silver objects with gold parts. It is suggested that vertical mixing lines (with constant $\mathrm{Pb}$ crustal age but variable $\mathrm{Au}$ ), may indicate the melting down and mixing of silver in times of unrest, both here and in other contexts. Gold and lead concentrations in the silver indicate that native silver from Iberia was most likely used in the Early Iron Age, suggesting that the first people to convey silver to the southern Levant were not miners but traders who had acquired silver directly from the indigenous Bronze Age inhabitants of Iberia. However, evidence of the exploitation of jarosite also supports that silver ore mining and cupellation was ongoing in Iberia at a similar time, and continued in the Late Iron Agepotentially a result of technological transfer from the East. In essence, the western Mediterranean origin of the silver in these Early Iron Age southern Levantine hoards supports an emerging picture of Mediterranean interactions and trade relations in the increasingly bright Dark Ages (c. 1200-800 BC).
\end{abstract}

Electronic supplementary material The online version of this article (https://doi.org/10.1007/s1096 3-018-09128-3) contains supplementary material, which is available to authorized users.

Extended author information available on the last page of the article 
Keywords Silver hoards · Mixing lines · Lead isotope analysis · Phoenicians ·

Reanalysis · Southern Levant

\section{Introduction}

In terms of geographical and chronological distributions, the largest identified concentration of silver hoards in the ancient Near East is in the Iron Age of the southern Levant (Thompson 2003). Unlike the Bronze Age hoards of this region, as well as those of Cyprus and the Aegean, which tend to be more mixed in terms of metals and materials, silver appears to be the preferred metal in these Iron Age contexts. The increasing frequency of silver in hoards in the Iron Age (in some cases to the exclusion of other metals) becomes all the more remarkable when it is considered that the southern Levant has no geological silver sources of its own (Thompson 2003). This raises questions regarding the origins of the hoard silver, as well as how and when it arrived in this region, with obvious implications for our understanding of the broader geopolitical context.

The hoards of Tel Miqne and Ein Gedi are both dated to the seventh-sixth centuries $\mathrm{BC}$ and can therefore be considered significant in relation to east-west Mediterranean trade (Gitin and Golani 2001), with its Assyrian and Phoenician connections (Aubet 1993, pp. 45-76, 266-273). By contrast, the hoards of Akko, Ashkelon, Bet Shean, Ein Hofez, Tel Dor, Tell el 'Ajjul, Tel Keisan and possibly Shechem and Eshtemoa are much earlier (Fig. 1; Table 1) (Thompson 2003), deposited at a time prior to the ninth century $\mathrm{BC}$, which is the commonly accepted period of Phoenician movement westward (e.g. Broodbank 2013, p. 489; Ruiz-Galvez 2014, pp. 196-214). Determining the source of this silver is thus potentially critical to our understanding of the origins of this trade. A western Mediterranean signature would suggest that western silver was acquired and conveyed much earlier than is usually accepted.

In essence, a western origin for the silver in these Early Iron Age southern Levantine hoards would provide some evidence for interactions between the east and west Mediterranean at a time when there is scant archaeological evidence of such interactions. Furthermore, the nature of such interactions between east and west would also be potentially significant. Russell and Knapp (2017) recently advocated that archaeologists should 'decouple foreign objects from foreign agents' by scrutinising the commonly held belief that prestigious or exotic goods necessarily indicate trade, whilst pottery or metallurgical tools must somehow indicate the presence of foreigners. However, these authors also recognise work by Jones and colleagues (Jones et al. 2014) on the presence and development of Italo-Mycenaean pottery, which proposed that Aegean people who settled in Italy helped facilitate the technological transfer required for the local potters to manufacture such wares. By the same rationale, any silver with a western Mediterranean signature found in the hoards of the southern Levant, which can also be recognised as having been smelted and cupellated by non-local agents, could suggest more than transient contact between the east and west. 


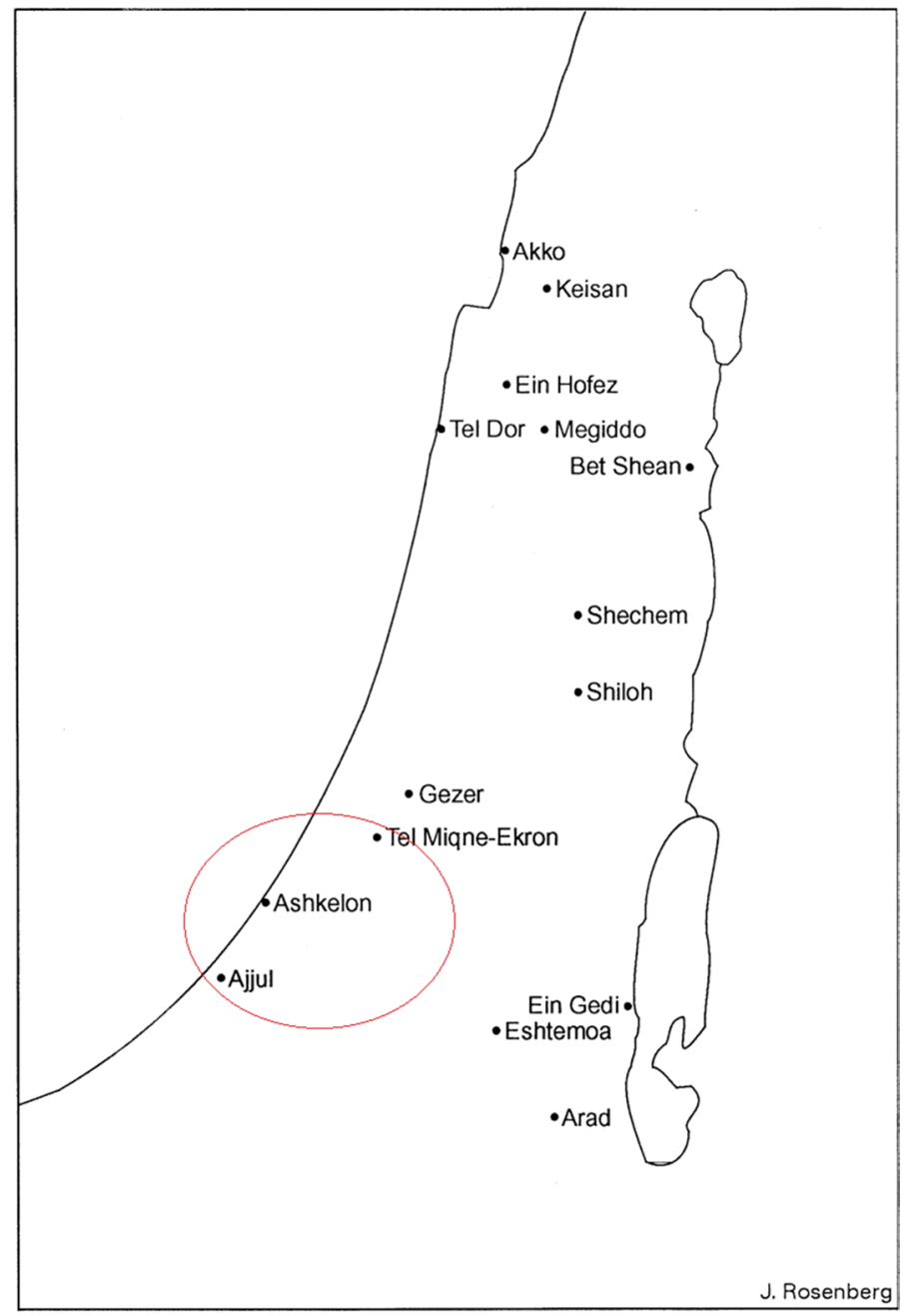

Fig. 1 Map of the southern Levant with the sites of hoards mentioned in the text. Adapted from Thompson (2003). The red line highlights the three hoards in the text in Philistia (Color figure online)

This paper is based on a reanalysis of isotopic and compositional data for silver hoards from the southern Levant and relevant data from geological sources in a new attempt to investigate their geological origins. We propose a new approach to data processing and visualisation that allows the identification of mixing lines when silver from different sources is mixed, and suggest how variable economic contexts may be hypothesised from the arrangement of such mixing lines. Behind the noisy signatures of recycled and mixed metals it is possible to identify potential sources and interesting patterns, throwing some light on the interaction between peoples within the southern Levant and across the Mediterranean. The results indicate that recycling of silver was almost ubiquitous throughout the Iron Age, and that 
Table 1 Sites and chronology for each hoard mentioned in the text. Adapted from Thompson (2003)

\begin{tabular}{|c|c|c|c|}
\hline Location & Chronology & $\begin{array}{l}\text { Number } \\
\text { of samples } \\
(\mathrm{N}=150)\end{array}$ & Weight of silver (g) \\
\hline Akko & 9th-8th century BC & 10 & 257.6 \\
\hline Ashkelon & Late 12 th century $\mathrm{BC} ? / 1100 \mathrm{BC}$ & 7 & $\begin{array}{l}\text { Bundle 1: } 44.9 \\
\text { Bundle 2: } 55.05\end{array}$ \\
\hline Bet Shean & 12th century BC & 5 & $\begin{array}{l}\text { Bet Shean: A 2423.8; B 2434.65; } \\
\text { C } 1332\end{array}$ \\
\hline Ein Gedi & $630-586 \mathrm{BC}$ & 5 & 1078 \\
\hline Ein Hofez & 10th-9th century BC? & 15 & $>1200$ \\
\hline Eshtemoa & 11 th -9 th (or 10 th -8 th) century BC & 15 & 26,000 \\
\hline Miqne-Ekron & 7th century BC/c. $600 \mathrm{BC}$ & 50 & $\begin{array}{l}\text { Miqne-Ekron A: 24.5; B 259.4; C } \\
\text { 954; D 89.7; E 73; F } 19\end{array}$ \\
\hline Shechem & $\begin{array}{l}\text { Late Bronze Age/Iron Age or } \\
\text { 1000-200 BC }\end{array}$ & 10 & $>45.16$ \\
\hline Tel Dor & 11th-10th century BC & 15 & 8500 \\
\hline Tell el ‘Ajjul & 12th-11th century BC & 10 & ? \\
\hline Tel Keisan & Second half of the 11th c. BC & 8 & 354 \\
\hline
\end{tabular}

The number of samples corresponds to number of artefacts analysed, i.e. fragments from various types of ingots, hacksilver, silver sheet, wires, rods, tokens, jewellery, as well as indeterminate fragments. The total weight of silver is also shown. The proportion of silver pieces analysed for each hoard varied. As a guide, 50 out of 305 pieces of silver from Miqne-Ekron were subjected to LIA

the components of this mixed silver originated from both the Aegean, Anatolia and the western Mediterranean. While acknowledging problems of dating, we present evidence that the west-east movement of silver potentially started as early as the 11th century BC. We discuss the implications of this new evidence for Mediterranean archaeology and archaeometallurgy.

\section{Previous Work}

In the 1980s and 1990s, 13 seasons of excavations at Tel Miqne in modern day Israel, identified as the ancient Biblical city of Ekron, resulted in finds of 6 hoards comprising 305 pieces of silver (Gitin 1995). The assemblages of pottery, ingots, hacksilver (deliberately broken silver objects) and damaged and fragmented pieces of jewellery pre-date the final destruction of the city by the Neo-Babylonian King Nebuchadnezzar during one of his campaigns to Philistia (most probably in 604 BC). Researchers concluded that most of the silver was collected for its value as bullion, perhaps for safe-keeping prior to the impending Babylonian attack (Porten 1981). Tel Miqne-Ekron is one of several sites in the ancient Near East with silver hoards dating from the late eighth century to the end of the seventh/beginning of the sixth century BC. Of those in the southern Levant, the Ein Gedi hoard has a secure date (630-582 BC) (Mazar 1993), while the date for hoard of Eshtemoa has been proposed as the eleventh-ninth centuries (Thompson 2003), the tenth-ninth 
centuries (Yeivin 1993) and the eighth century BC (Kletter and Brand 1998). As such, these hoards could be considered part of the corpus of late Iron Age II silver currency hoards that are found across the Near East, pointing to the growing fiscal needs of an international economy in the seventh century BC, with silver being the commodity that was required to develop Neo-Assyrian economic interests (Postgate 1973, p. 25, 1979; Frankenstein 1979, p. 287).

Thompson (2003) investigated 35 Iron Age silver hoards from 13 sites across Cis-Jordan (Israel and the lands under the Palestinian Authority), including those mentioned above. Importantly, some of these hoards are earlier than Tel MiqneEkron, Ein Gedi and possibly Eshtemoa and Shechem; Thompson suggested that the dramatic increase of silver deposition in the Levant started in the Early Iron Age. This hypothesis appears to be supported by the replacement of gold with silver as the main metal for complex jewellery (Gilboa 2013 citing Golani 2009). Furthermore, lead isotope analyses (LIA) were used to support the argument that some of the silver from these Early Iron Age contexts originated from ores in the Aegean and Sardinia (Thompson and Skaggs 2013, citing Thompson 2007). The basic argument was that Philistine sites such as Ashkelon, and Phoenician sites such as Tell Keisan and Tel Dor, although not in Phoenicia proper (Gilboa 2013), had silver that was isotopically consistent with the west Mediterranean. More recently, Thompson and Skaggs (2013) used LIA data from 25 of the sampled artefacts (from Akko, Ein Hofez, Tel Dor and Tell Keisan) to show that they are consistent with ores of the central and western Mediterranean, and are inconsistent with the ore deposits of Anatolia (Taurus) and the Aegean (Laurion). Relating this evidence to ancient documents, which suggest that the land of Tarshish was the source of King Solomon's silver, these authors proposed a location for Tarshish in Iberia or Sardinia as part of a transient, pre-colonial Phoenician metals trade.

Analyses based solely on lead isotopes, however, have proved to be controversial, owing to issues of recycling, alloying and mixing (Gale et al. 1984), as well as the possible use of exogenous lead for cupellation (Murillo-Barroso et al. 2016). Even though an object may match the isotopic signature of an ore field, this does not necessarily mean that the ore field was mined for silver, or even that silver was (or is) present in extractable amounts. Furthermore, only some of the silver samples in the hoards analysed seems to have this west Mediterranean isotopic signature, raising the question of where the rest of the silver came from. Nevertheless, Thompson and Skaggs' (2013) method of iteratively matching isotopic signatures of the silver in the hoards to a selection of (predominantly lead) ores from the western Mediterranean strongly suggests that silver from the west Mediterranean was being brought to the southern Levant in the Early Iron Age.

Mixing of metals is problematic not only for LIA but also for minor or trace element compositional signatures, which may be diagnostic of an ore when the metal is unalloyed but can become blurred when another metal (or the same metal from another ore source) is introduced into the melting pot. Even so, as any mixture can only be made when each component is accessible to the people doing the recycling, the identification of mixing can provide a window through which to view connectivity, as well as delimiting the chronology of such connections. 
Mixing can be intentional or unintentional. Whereas copper is often deliberately alloyed with silver in order to improve the mechanical properties of the alloy (Rehren et al. 1996), and levels of lead in silver are affected by the efficiency of the cupellation process (Pernicka 1990), gold is present in silver as a natural trace element-an element considered to be associated solely with silver sources and not significantly altered by the smelting and cupellation processes (Gitler et al. 2009). The variability in gold concentrations between silver artefacts has been used successfully to differentiate between generic lead-silver ore types, with an empirical value of $0.1 \mathrm{wt} \% \mathrm{Au}$ in silver objects being the upper limit for silver derived from galena (Butcher and Ponting 2014, p. 102). In such cases, the gold content of silver is a useful discriminator when trying to reconcile LIA and compositional data.

Gold is unlikely to be added deliberately to silver for several reasons: it does not change the colour of silver unless very high amounts are added (a level of 20\%, or even $30 \%$, gold would not alter the colour of a silver alloy), or make processing easier. In fact, it raises the melting point of the system (Rehren et al. 1996). It is also a metal that was valued in its own right. This suggests that elevated levels of gold in ancient silver are either from silver-bearing ores with high levels of gold, or that gold was added unintentionally through recycling of objects with gilt or gold parts that were not removed prior to being mixed with other silver.

Lucas (1928) advocated for exploitation of extremely rich electrum deposits, long since exhausted, from the eastern desert region of Egypt as a potential source of auriferous silver in ancient silver. Rehren et al. (1996), however, noted that Egyptian aurian silver does not appear to have a geological basis, highlighting the rarity of gold-bearing metallic silver generally. Rehren and colleagues suggested unintentional alloying as the origin of most auriferous silver, especially in areas where silver was not available locally, accentuating the need to economise on scarce raw materials through recycling. In other words, gold concentrations in the silver will rise if, for example, gilded parts (a few micrometres thick) or a handle made of gold (or electrum) were not removed from, say, a silver cup before it was melted to produce the less bulky ingots and hacksilver that are more easily concealed in a hoard.

\section{Reanalysis of Legacy Data}

The LIA results of the silver hoards of the southern Levant are openly available as part of the corpus of first millennium BC silver on the Oxalid (2018) database, along with compositional analyses of the gold, copper and lead concentrations of the silver. Compositional data were not used explicitly until recently, however, when a study of the composition and microstructure of silver hoards from Tel Bet-Shean, Tel Dor and Tel Miqne-Ekron noted that the typical composition is silver with several percent of $\mathrm{Cu}$ and $\mathrm{Au}$ and less than $1 \%$ lead (Shalev et al. 2014). This study also noted that the concentrations of these metals vary significantly within each hoard. It was concluded that only the silver from Tel Miqne-Ekron had a low gold content consistent with values typical of Greek silver (from argentiferous galena), while the higher gold content in the silver samples from Bet-Shean and especially Tel Dor 
were proposed to be much closer to those of ancient Egyptian silver, possibly from alluvial deposits (Shalev et al. 2014).

In some respects, the results of the LIA and the compositional analyses are in conflict. LIA data suggest ore sources from the Aegean and the western Mediterranean for a part of the hoard corpus, while compositional analyses point toward silver from the Aegean and a presumably exhausted Egyptian ore source. The gold content of the silver appears to be the main issue when trying to reconcile LIA and compositional data. For example, from LIA, the silver used to make the objects in the hoards from Bet Shean indicates an Anatolian or, to a lesser degree, a Laurion ore source (Thompson 2009), but the gold content of this silver (up to 3\% Au) is in excess of that found in silver from these areas. Thompson and Skaggs (2013), discussing silver found in the hoards, emphasise that the high levels of gold (mean $=1.8 \% \mathrm{Au}$, $\max =35 \% \mathrm{Au}$ ) in some samples are not well understood.

To address some of the inconsistencies between the LIA and compositional analyses, the two datasets have been combined and analysed together (Wood et al. 2017). In order to facilitate this, lead isotopes $\left({ }^{207} \mathrm{~Pb},{ }^{206} \mathrm{~Pb}\right.$ and $\left.{ }^{204} \mathrm{~Pb}\right)$ were used to calculate the $\mathrm{Pb}$ crustal age of the ore from which the silver originated. This calculation omits information from ${ }^{208} \mathrm{~Pb}$ and thus cannot be considered a replacement for traditional lead isotope plots in all cases (which may allow variability in specific ratios to identify differences between objects and ores). However, it is an alternative approach that reduces the complexity of lead isotopes to a single variable and thus makes it easier to analyse alongside trace element data.

Crustal ages (also known as model ages) were calculated from lead isotope data using a two-stage evolution model with the common $\mathrm{Pb}$ isotope composition and the ${ }^{238} \mathrm{U} /{ }^{204} \mathrm{~Pb}$ of the crust (Stacy and Kramers 1975; Albarède and Juteau 1984; Desaulty et al. 2011). The calculations were performed using the approach outlined by Desaulty et al. (2011) and by applying their parameters to determine the Pb crustal age. Different parameters are used by different groups of researchers, and the same groups often update the parameters they use (e.g. Albarède et al. 2012). The aim here, however, is not to calculate crustal ages per se but to define a value for both the ore sources and the associated objects: both should have the same lead isotope ratios and hence the same $\mathrm{Pb}$ crustal age, whether or not this corresponds with the actual geological date. In fact, the calculations sometimes yield negative values (i.e. future ages). This could mean that these leads have had a more complicated history than might be expected from the predicted rate of addition of radiogenic lead in the source region, during which they acquired extra amounts of radiogenic lead. Alternatively, it could mean that the model or the parameters are not sufficiently refined to represent the full range of ages. Nevertheless, for the purposes of this paper, the parameters used to calculate crustal ages for both the ores and objects were the same.

All available data from the Oxalid (2018) first millennium BC silver database were used from the hoards found in Israel and the lands under the Palestinian Authority. This lack of selection (i.e. by site, chronology etc.) was deliberate, as it is the connectivity potentially illustrated by the whole dataset that was of interest, before more nuanced interpretations. Table 1 shows the sites and chronology for each hoard, with tentative dates indicated by a question mark. The weight of 
Fig. 2 Frequency histograms of $\mathbf{a} \mathrm{Au} / \mathrm{Ag} \times 100$ (top) and $\mathbf{b} \mathrm{Pb}$ crustal age (Ma) (bottom) for the full dataset of silver hoards found in the southern Levant. $\mathrm{Pb}$ crustal ages were calculated from LIA data on the first millennium BC silver database (Oxalid 2018) using the two-stage evolution model with parameters from Desaulty et al. (2011)

the silver in the hoards is also listed. Figure 1 shows a map of the locations of the hoards. The compositional and lead isotopic data, as well as the calculated model ages ( $\mathrm{Pb}$ crustal age) of the ores and the $\mathrm{Au} / \mathrm{Ag}$ ratios, can be found in Online Resource 1.

Reliable chronology is clearly essential to interpret the significance of these hoards, but unfortunately it is not always available with the desired precision. We are therefore using the most generally accepted chronological attributions but appreciate that some may be revisited in the future. Our preferred date of the Eshtemoa hoard, for example, is the earlier date (i.e. 11th-9th centuries BC): the eighth century BC re-dating by Kletter and Brand (1998) was suggested as it was closer to the dates of the hoards already published, that is, prior to publication of the hoard from Tel Dor. For this reason, it has been reanalysed alongside the earlier hoards (see Fig. 5). Similarly, the Shechem hoard is probably earlier than the eighth-seventh centuries BC, as the site has occupational phases around this time and because coins, often found in assemblages from later periods, were not found in the hoard (Gitin and Golani 2001). The Bet Shean hoard has been dated to the 13th-11th centuries BC (Shalev et al. 2014), which is commensurate with the 12th century BC chronology reported by Thompson (2003). The two hoards found at Philistine Ashkelon are suggested to be from around 1100 BC (King and Stager 2001). A recent article on the hoards of Tell Keisan, Tel Dor, Ein Hofez and Akko (Eshel et al. 2018) presents slight modifications of dates.

\section{Mixing Lines}

Figure $2 \mathrm{a}$ is a frequency distribution histogram of $\mathrm{Au} / \mathrm{Ag} \times 100$ for the full dataset. $\mathrm{Au} / \mathrm{Ag}$ was plotted rather than $\mathrm{Au} \%$ to account for dilution, mainly due to variable addition of copper. As copper is not generally associated with gold, the Au/Ag ratio can facilitate comparisons between objects and argentiferous ores. In any case, as the majority of samples are predominantly silver (>95 wt \%), the $\mathrm{Au} / \mathrm{Ag} \times 100$ and $\mathrm{Au} \%$ are similar in most cases.

This figure shows that $\mathrm{Au} / \mathrm{Ag}$ levels are very low for most of the samples. $\mathrm{Au} /$ $\operatorname{Ag} \times 100>1$, however, holds for about a third of the samples, with two outliers having very high levels. Figure $2 \mathrm{~b}$ is a histogram of the $\mathrm{Pb}$ crustal ages (Ma) determined from the LIA ratios for the full dataset. The majority of the samples show very young crustal ages, with those around zero being consistent with the ores at Laurion (Fig. 3). However, a range of ages is evident with those around $200 \mathrm{Ma}$ and $350 \mathrm{Ma}$ exhibiting higher frequencies. There are three outliers at around 600 Ma. Figure 3 also highlights that Archaic Athenian coins (which are 

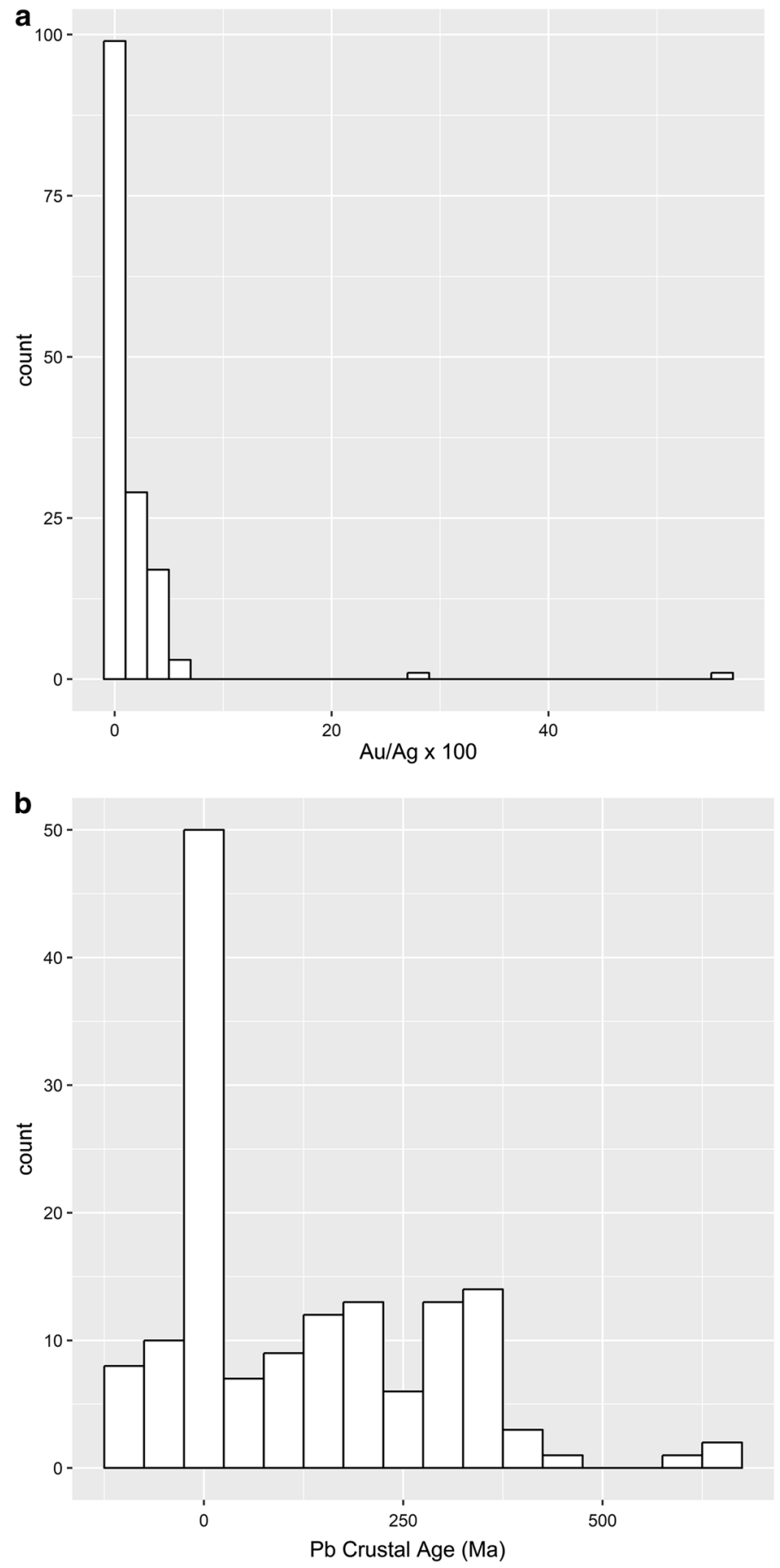


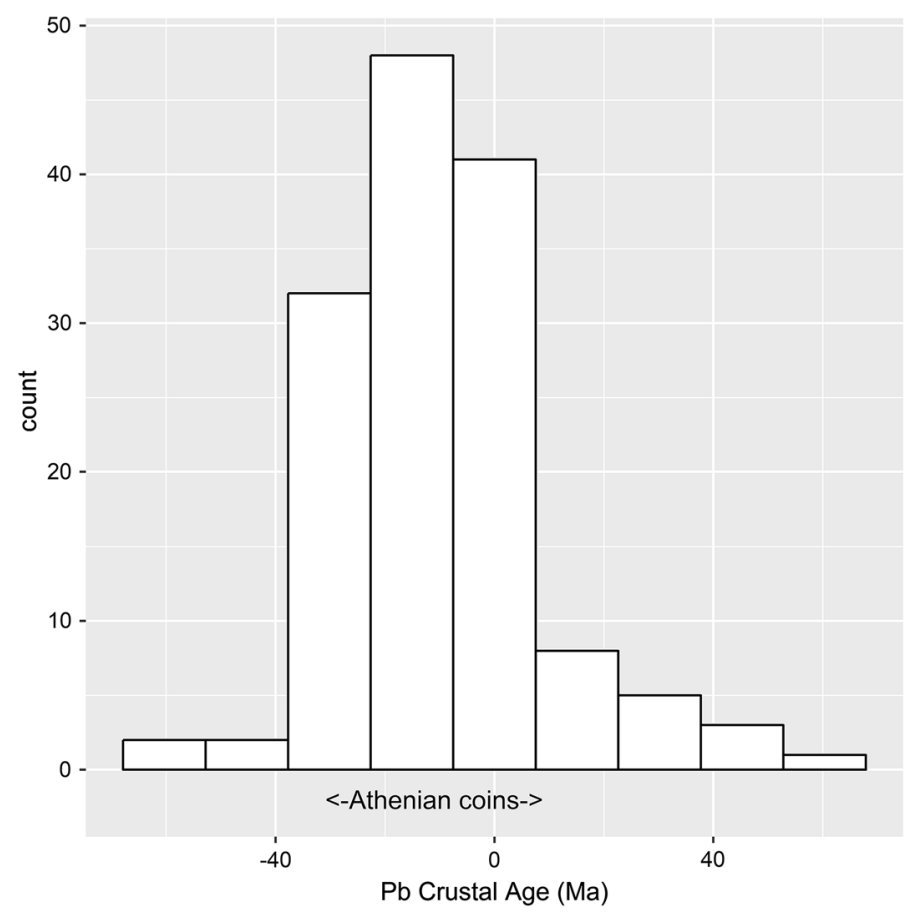

Fig. 3 Frequency histogram of the $\mathrm{Pb}$ crustal age (Ma) for ores from Laurion, as calculated from the lead isotopes from the Greek ores database (Oxalid 2018) using the two-stage evolution model with parameters from Desaulty et al. (2011). The range of calculated $\mathrm{Pb}$ crustal ages for Athenian coins from the Asyut hoard (Gale et al. 1980) is also presented and shows that these coins are commensurate with silver mined from Laurion

considered to derive from Laurion: Gale et al. 1980) lie within the limits of the crustal ages of the Laurion ore field (this can also be observed on traditional LIA mirror plots in Figs. 5 and 7).

Figure 4 shows $\mathrm{Au} / \mathrm{Ag}$ versus $\mathrm{Pb}$ crustal age for the two most recent hoards, Ein Gedi and Miqne-Ekron, which are dated to the seventh century BC. A cluster is apparent at low crustal ages (around $0 \mathrm{Ma}$ ) and low gold concentrations (Au/ $\mathrm{Ag} \times 100 \sim 0.2)$ from the hoards at Miqne-Ekron. It should be noted that the detection limit for these ED-XRF measurements was about $0.2 \% \mathrm{Au}$ as indicated by the horizontal black dotted line. As such, the cluster appears more pronounced, as any value described as $<0.2 \mathrm{Au} \%$ was given the value $0.2 \mathrm{Au} \%$. The lower plot in Fig. 4 presents hand-drawn lines through the points. This process, albeit subjective, was considered preferable to fitting the data using linear trend lines, as it is unknown $a$ priori which points correspond to which mixing line. Essentially, these lines (and the lines in the lower plot in Fig. 6) are our interpretations of the patterns we observe in the data, and we appreciate that other interpretations could be made.

The green dashed line probably extends to even lower levels of $\mathrm{Au} / \mathrm{Ag}$ than indicated on the plot because of the detection limits of the ED-XRF. This line 

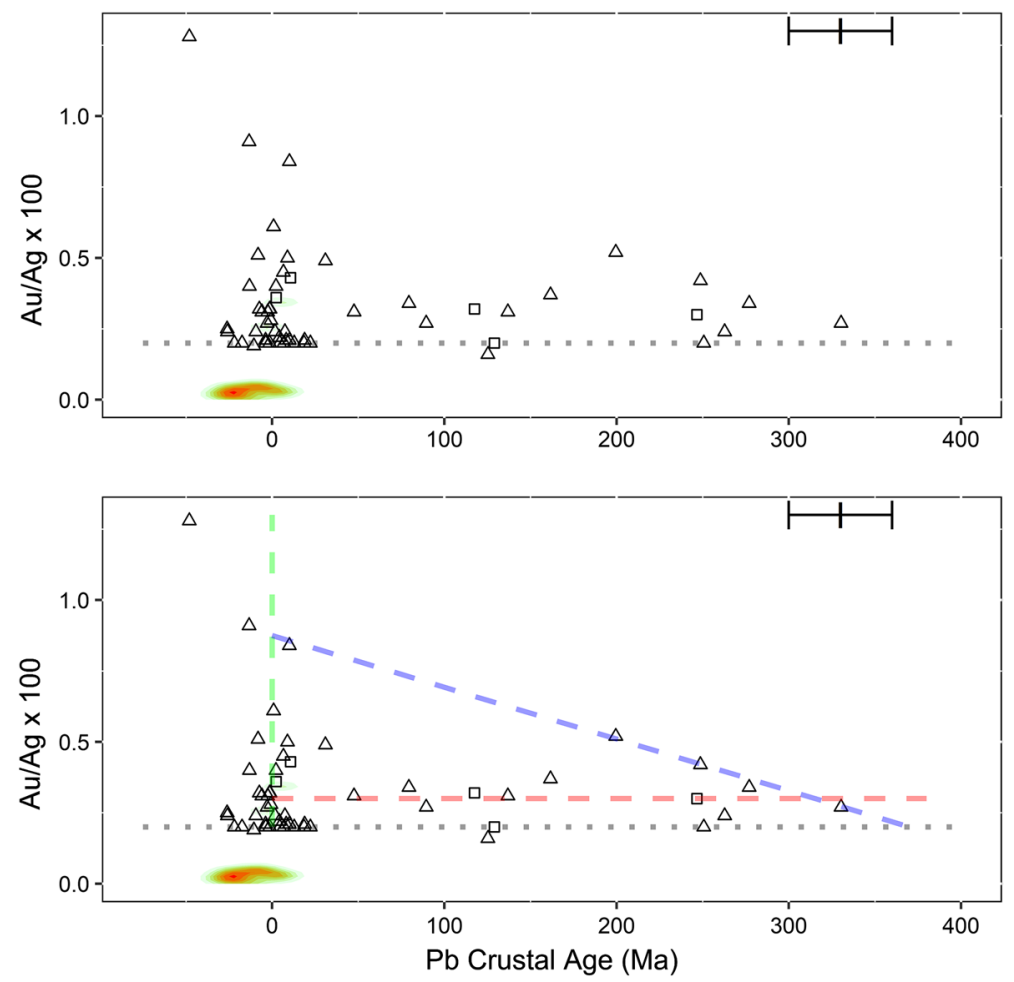

Fig. $4 \mathrm{Au} / \mathrm{Ag} \times 100$ versus $\mathrm{Pb}$ crustal age $(\mathrm{Ma})$ for the seventh century $\mathrm{BC}$ hoards of Miqne-Ekron (triangles) and Ein Gedi (squares). The density map (high density: red; low density: green) is derived from compositional data (measured by NAA) and lead isotope data for Athenian coins found in the Asyut hoard (c. 475 BC), which is taken here as representative of Laurion silver (Gale et al. 1980). The black dotted line shows the detection limits from the ED-XRF technique used to measure the composition of the hoard data. The hand drawn lines in the lower plot are described in the text. The error bar was determined by propagating the error on lead isotope ratios $( \pm 0.1 \%)$ to the $\mathrm{Pb}$ crustal age (Color figure online)

highlights that although many samples have various levels of $\mathrm{Au} / \mathrm{Ag}$, the crustal age is relatively constant (around $0 \mathrm{Ma}$ ). This pattern could be a consequence of the use of different ore sources with similar crustal ages but different gold levels (up to $\mathrm{Au} / \mathrm{Ag} \times 100 \sim 1.25$ ). Nonetheless, although ores with high gold levels exist (e.g. argentiferous cerussite sources have gold levels which could cover this range), it is unlikely that different ore sources even within the same deposit would have crustal ages that result in such an invariant plot with such a wide range of gold levels (i.e. the green dashed line).

A more probable interpretation is that the variation in gold concentration along the green dashed line is a consequence of silvers from the same ore source (but with different gold levels) being mixed together, that is, higher levels of Au/Ag probably resulted from silver from the same ore source being unintentionally mixed with gold. The cluster of silver with low gold levels around 0 Ma suggest that one of the components was silver derived from the galena ores of Laurion on the Attic peninsula 

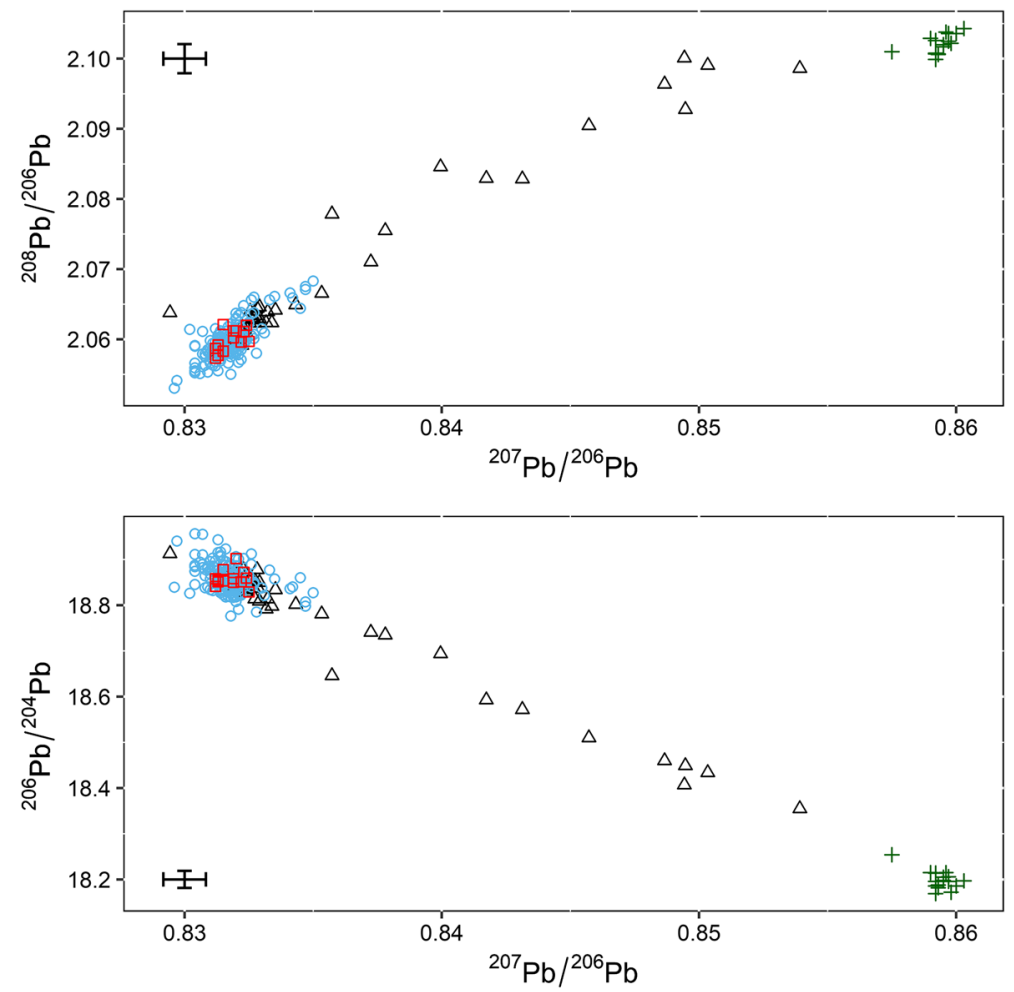

Fig. 5 LIA mirror plots showing that Athenian coins (red squares) and some silver from the hoard at Miqne-Ekron (black triangles) is consistent with ores from Laurion (blue circles), and that the remainder of the Miqne-Ekron silver hoard lies on a line that extends to the argentiferous ores of the Pyritic Belt in southwest Spain (green crosses). The error bars indicate $\pm 0.1 \%$ (Color figure online)

(i.e. the cluster is commensurate with the $\mathrm{Pb}$ crustal ages of Laurion ores shown in Fig. 3). This is further supported by the density plot of Athenian coins, which are believed to derive from the silver ores of Laurion (Gale et al. 1980). Although these coins show a much lower Au/Ag level than the hoard silver, this is probably because the coins were measured using neutron activation analysis (NAA), which has lower (i.e. better) detection limits than ED-XRF. In other words, in agreement with Thompson and Skaggs' (2013) traditional LIA plots, which showed that some of the sampled silver from Miqne-Ekron was consistent with the ores of Laurion, Fig. 4 indicates that Miqne-Ekron had access to silver from Laurion in the seventh century BC.

More evidence of mixing can be observed for silver running along the $\mathrm{Pb}$ crustal age axis (the red dashed line). If silver with a higher crustal age was mixed in various proportions with silver from the cluster at $0 \mathrm{Ma}$, a series of silvers with relatively invariant gold levels but large differences in crustal ages would be produced. The silver from these mixtures ended up, perhaps unsurprisingly, in hoards at Miqne-Ekron as well as at Ein Gedi. As no cluster is present at high crustal ages 

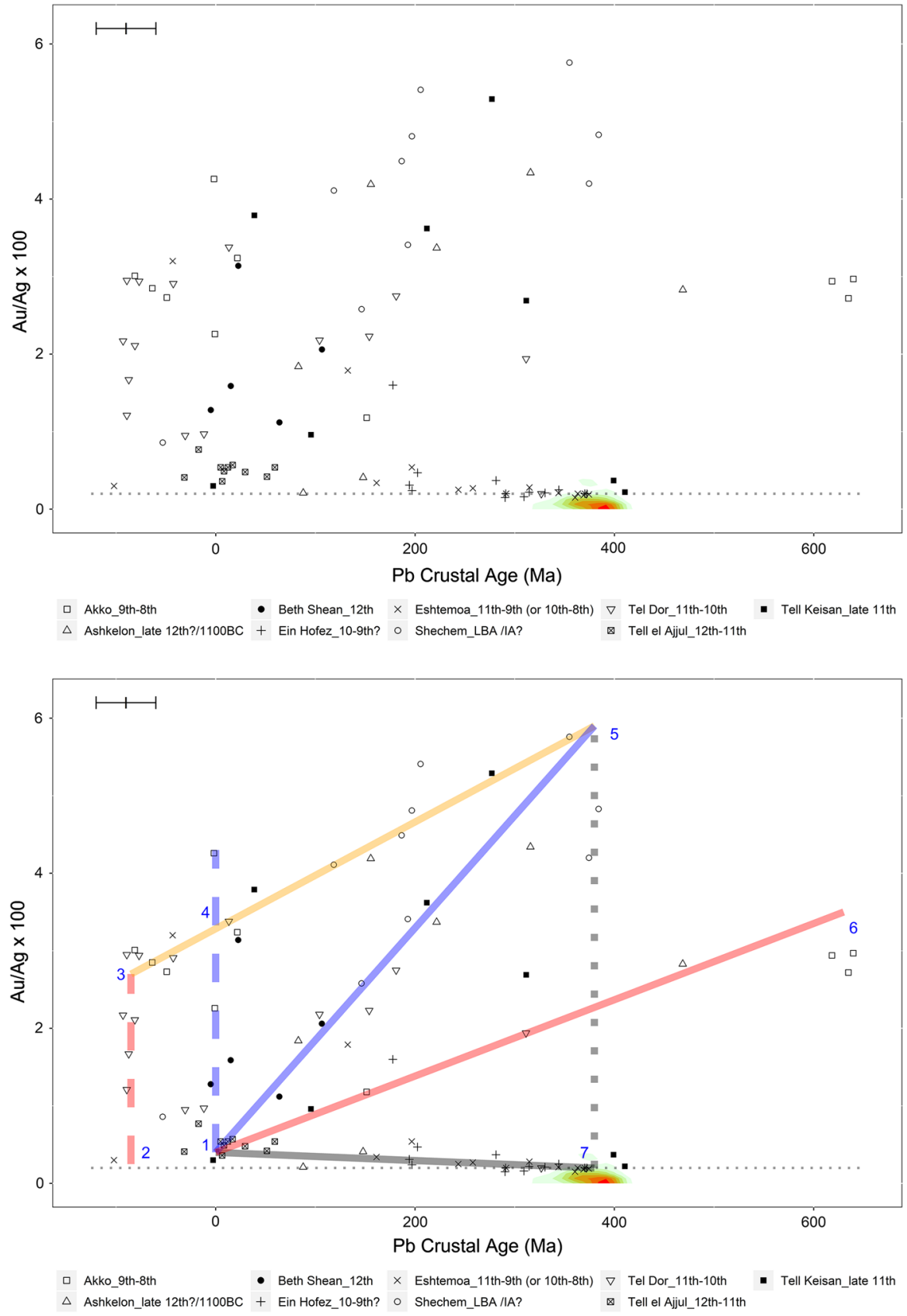

Fig. $6 \mathrm{Au} / \mathrm{Ag} \times 100$ versus $\mathrm{Pb}$ crustal age $(\mathrm{Ma})$ for the Late Bronze Age/Early Iron Age hoards. The density map (high density: red; low density: green) is derived from compositional data (measured by ED-XRF) and lead isotope data for Bronze Age silver found in Iberia (Comendador Rey et al. 2014; Bartelheim et al. 2012; MurilloBarroso et al. 2015; Murillo-Barroso 2013). The black dotted line shows the detection limits from the ED-XRF technique used to measure the composition of the hoard data. The hand drawn lines and the numbered points in the lower plot are described in the text. The error bar was determined by propagating the error on lead isotope ratios $( \pm 0.1 \%)$ to the $\mathrm{Pb}$ crustal age (Color figure online) 

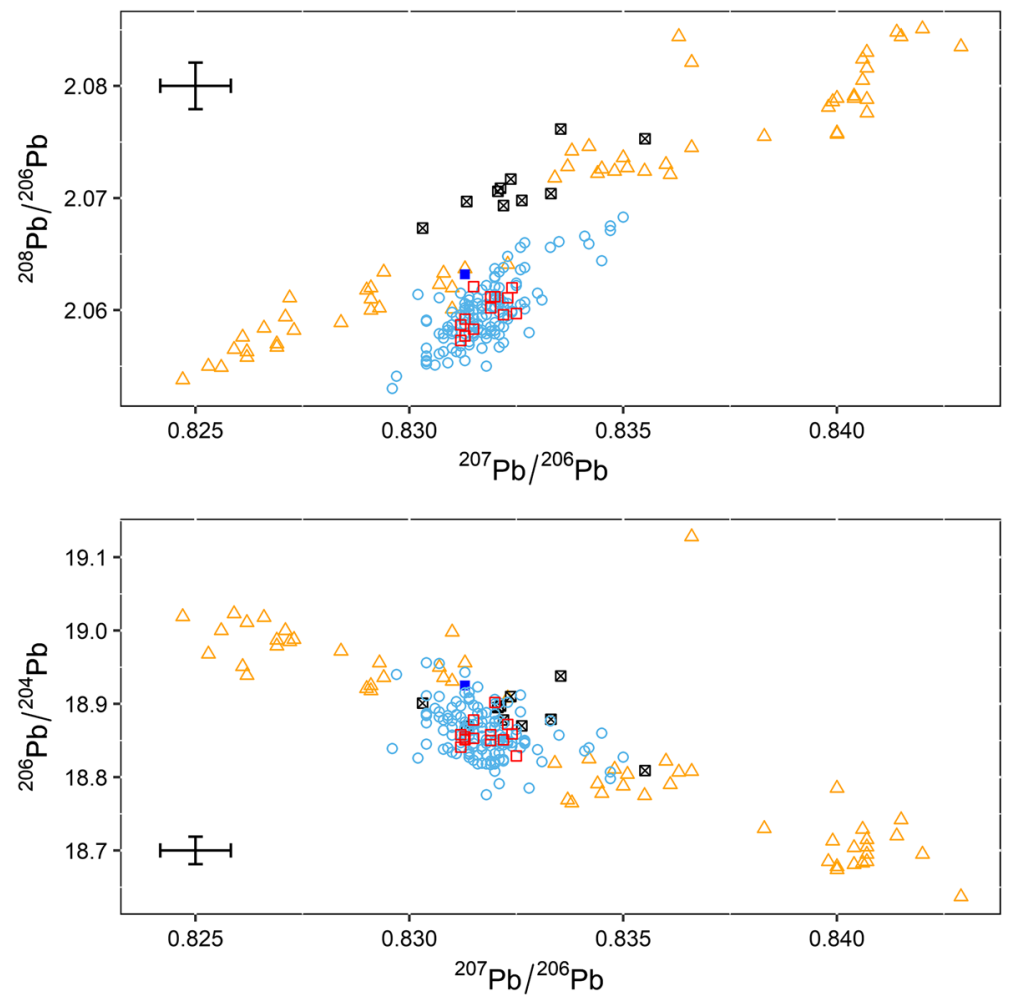

Fig. 7 LIA mirror plots showing that silver from Athenian coins (red squares) is consistent with ores from Laurion (blue circles) and that Laurion ores are generally distinct from the ores of the Taurus mountains in Anatolia (brown triangles) on the ${ }^{208} \mathrm{~Pb} /{ }^{206} \mathrm{~Pb}$ vs ${ }^{207} \mathrm{~Pb} /{ }^{206} \mathrm{~Pb}$ plot. This suggests that the silver from Tell el 'Ajjul (black crossed squares) (cluster 1 in Fig. 6) derives from the Taurus mountains, whereas the single silver sample from Tell Keisan (blue square) in the same cluster could derive from either Laurion or the Taurus mountains. The error bars indicate $\pm 0.1 \%$ (Color figure online)

on this plot it is difficult to determine the end member of such a mixing line. Even so, this is clearly over $300 \mathrm{Ma}$, which rules out Aegean and Anatolian ores. The blue dashed line shows, perhaps optimistically, a mixing line between silver from a high crustal age source with a low crustal age source which has a higher gold level than that from Laurion, that is, potentially silver from Laurion that had been mixed with gold to a level of $\mathrm{Au} / \mathrm{Ag} \times 100 \sim 0.9$. As mentioned above, these lines are subjective, and more convincing examples of such lines are presented below in Fig. 6. Nevertheless, this mixing potentially produced silver with intermediate levels of both gold concentration and $\mathrm{Pb}$ crustal age. The intersection of the blue and red dashed line would support that a high crustal age/low gold silver source was available at Phoenician-influenced Miqne-Ekron during the seventh century BC.

To further support that the silver from the Miqne-Ekron hoard is made up of argentiferous ores from Laurion and mixed silver from elsewhere, Fig. 5 shows LIA mirror plots for Laurion ores, Athenian coins and silver from the Miqne-Ekron 
hoard. The Athenian coins and some of the Miqne-Ekron hoard are consistent with Laurion ores on both plots. What is also apparent is that the remainder of the MiqneEkron hoard lies on a line toward LIA values derived from the ores of the Pyritic belt of southwest Spain (Stos-Gale et al. 1995; Pomiès et al. 1998), areas which have crustal ages which range between $376 \mathrm{Ma}$ and $418 \mathrm{Ma}$ (calculated from the LIA data: Oxalid 2018), reflecting their Hercynian orogenies. This suggests that the some of the silver found in the hoard of Miqne-Ekron was a mixture of silver from the province of Huelva in Spain and Laurion in Greece, that is, the red and blue dotted lines in Fig. 4. Moreover, the plots indicate that the provenance postulate is upheld, in that the variation between sources (i.e. Laurion and southwest Iberia) is greater than the variation within sources (as suggested by the Athenian coins) on the $\mathrm{Pb}$ crustal age plots (Fig. 4) and the traditional LIA plots (Fig. 5).

This approach is now applied to the rest of the dataset (i.e. the samples from the Late Bronze Age and Early Iron Age) (Fig. 6). The two extremely high Au/Ag values from Ein Hofez $(\mathrm{Au} / \mathrm{Ag} \times 100 \sim 27$ and 56) are not shown due to scale, but also because such high gold levels could have resulted from intentional mixing, perhaps to alter the colour of the alloy. As with Fig. 4, the upper plot in Fig. 6 presents Ag/ $\mathrm{Au} \times 100$ against the $\mathrm{Pb}$ crustal age (Ma) for the dataset, with our interpretations of the patterns in the lower plot.

The cluster at (1) in Fig. 6 includes silver from hoards at the Bronze Age site of Tell el 'Ajjul and one sample from Tell Keisan. In terms of Pb crustal age, this cluster is similar to the Miqne-Ekron cluster in Fig. 4. As in Fig. 4, the gold content of this cluster of hoard silver appears higher than that of the Athenian coins. A potential reason for this is in the aforementioned differences in measurement technique (ED-XRF vs. NAA). This cluster $(\mathrm{Au} / \mathrm{Ag} \times 100 \sim 0.5)$, however, is higher than that from Miqne-Ekron. This could be a result of more intense mixing (increasing average gold levels), but could also reflect the exploitation of more auriferous ores. When we examine these data in conventional LIA plots, we can observe that the most likely source for the bulk of the silver in this cluster is in the Taurus mountains of southern Anatolia, rather than Laurion (Fig. 7).

More importantly, this silver with a low crustal age and low levels of gold appears to be one component of a series of mixing lines generated throughout the Early Iron Age (Fig. 6) - this type of silver was available as early as the 12th century BC in the southern Levant. In other words, although several other clusters are evident in Fig. 6, it is the relatively linear lines which provide the rationale behind the plot. These linear lines suggest that two components were mixed together at any one time (even though the chronologies reflect different periods of deposition). In effect, although a cluster would probably be observed if three or more sources (with different crustal ages and gold concentrations) had been placed in the same mixing pot together, the lines would not be linear and extend to the signatures of potential ore sources. Essentially, the plots show a series of mixing lines deduced from the silver deposited in these Early Iron Age hoards which, as with those in Fig. 4, are our attempts to highlight patterns in the datasets. These mixing lines are now addressed.

The dashed blue line extending vertically from (1) corresponds closely to the previous explanation of the dashed green line in Fig. 4. This suggests that the type of silver available for the Bronze Age hoards at Tell el 'Ajjul was mixed with silver of 
a similar crustal age containing higher levels of gold (4). Silver from three objects from the hoard at Akko appears to fall on this vertical mixing line, having $\mathrm{Au} /$ $\mathrm{Ag} \times 100$ levels of about 2.3, 3.2 and 4.3. Silver from Bet Shean and Tel Dor also appears to lie on this line. Such a mixing line further supports the suggestion that silver originating from the Taurus mountains (see Fig. 7) was available at Tell el 'Ajjul in the 12th-11th centuries BC, Bet Shean in the 12th century BC, Tel Dor in the 11th-10th centuries BC, and at Akko in the 9th-8th centuries BC.

The cluster at (3) comprises silver from hoards at Tel Dor and Akko, with a vertical line (red dashed) extending to (2). The hoards along this mixing line are predominantly from Tel Dor, potentially suggesting that the mixing took place there. The $\mathrm{Pb}$ crustal age of this mixing line appears too young for the silver source to be Laurion (see Fig. 3) and it is therefore potentially from another argentiferous deposit. Again, the Taurus mountains in Anatolia could be a candidate as the crustal ages range from -130 Ma to $172 \mathrm{Ma}$ (calculated from Oxalid data, 2018), although Thompson and Skaggs (2013) discounted an Anatolian source for the hoard silver from the Tel Dor. From LIAs of ores around the Aegean (Oxalid 2018), only Thera (-51 Ma to -99 Ma) and Kythnos (-28 Ma to -61 Ma) appear to have silver-bearing ores (Gale and Stos-Gale 1981a) and Pb crustal ages commensurate with this mixing line. Further afield, Cyprus has $\mathrm{Pb}$ Crustal ages (190 Ma to -225 Ma) that also match, potentially re-opening the debate as to whether silver on Cyprus was mined during this period. However, we should emphasise that there is no archaeological evidence for silver mining at this time in any of these locations (Gale and Stos-Gale 1981a).

The solid blue line extends from the cluster at (1) through silver found in the hoards at Ashkelon, Shechem, Tel Dor, Tell Keisan and Bet Shean. In this case, the linear mixing line suggests that two components with very different gold levels and $\mathrm{Pb}$ crustal ages were mixed together, with the lower component being similar to the silver found in the hoards of Tel el 'Ajjul and Tell Keisan, that is, silver from Taurus. The orange mixing line between (3) and (5) also suggests that two components with very different gold levels and $\mathrm{Pb}$ crustal ages were mixed together. Although it is difficult to determine whether the orange line extends from (3) or (4), a mixing line can be drawn through silver from hoards at Shechem, Tell Keisan, Ashkelon, Akko, Tel Dor and Eshtemoa. The blue and orange lines appear to converge at (5), which would represent an end member of these mixtures. There is no cluster at (5), but the intersect suggests that silver from older ores (about $380 \mathrm{Ma}$ ) with high levels of gold $(\mathrm{Au} / \mathrm{Ag} \times 100 \sim 5.8)$ was not only mixed with 'pure' silver from Taurus ores (blue line) but also with silver with elevated levels of gold (orange line). The silver with elevated gold levels could have derived from Taurus (4) or from one of the younger ore sources discussed earlier (3). Again, regardless of the exact mixing mechanism, these two mixing lines (the blue and orange lines) suggest that silver with high gold and a high crustal age (380 Ma) was available throughout this region at least as early as the 11 th century BC.

Figure 8 is a frequency distribution histogram of the crustal ages of ores from Iberia and Sardinia, clearly showing the bimodal distribution resulting from Alpine (<90 Ma) and European Hercynian orogenies ( 250 Ma-400 Ma) found in Iberia (Desaulty et al. 2011), and the Hercynian and Caledonian orogenies found in Sardinia (Valera and Valera 2005; De Caro et al. 2013). Silver with a Pb 


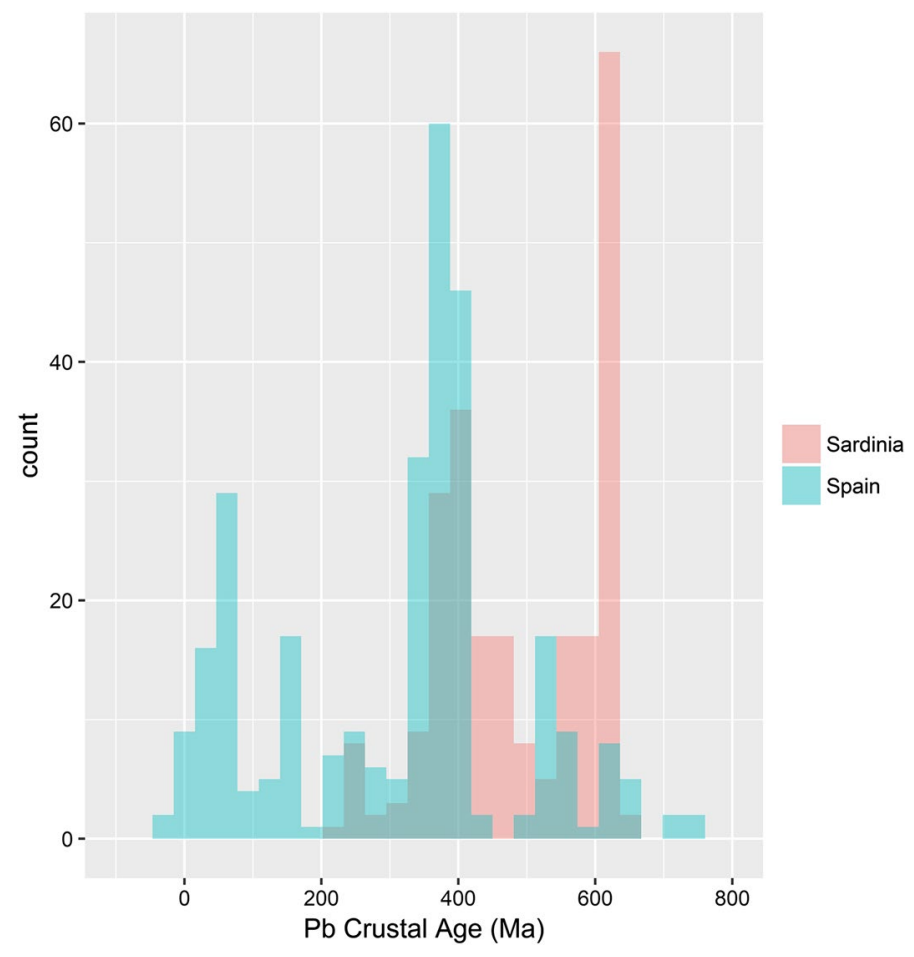

Fig. 8 Frequency histogram of the $\mathrm{Pb}$ crustal age (Ma) for ores from Iberia and Sardinia (from LIA data in Thompson and Skaggs 2013) showing overlapping areas, as calculated from the lead isotopes using the two-stage evolution model with parameters from Desaulty et al. (2011)

crustal age of 380 Ma could have originated from ores in either of these regions, and thus any silver lying on the orange and blue mixing lines was potentially mixed with silver deriving from Iberia or Sardinia. This would support Thompson and Skaggs' (2013) hypothesis of 'the Western Mediterranean as a silversupplying region to Phoenicia prior to colonisation'.

The vertical black dotted line on Fig. 6 (above, between points 5 and 7) shows that the intersection of the blue and orange mixing lines at (5) is coincident in terms of $\mathrm{Pb}$ crustal age with a cluster of silver from hoards at Ein Hofez, Tel Keisan and Eshtemoa (7). Despite their similar Pb crustal ages, the cluster at (7) has much lower gold levels $(\leq 0.2 \%)$. One question is whether the silver with high $(\mathrm{Au} / \mathrm{Ag} \times 100 \sim 5.8)$ and low $(\mathrm{Au} / \mathrm{Ag} \times 100 \leq 0.2)$ concentrations of gold at $380 \mathrm{Ma}$ derives from the same ore source. If so, this would suggest that silver from the low-gold ore had been mixed to produce silver with $\mathrm{Au} / \mathrm{Ag} \times 100$ of nearly 6 . However, as there is not a convincing number of samples that lie on a vertical mixing line between 5.8 (5) and 0.2 (7) at $380 \mathrm{Ma}$, it is speculated that the silver with the $380 \mathrm{Ma}$ crustal age reflects two different types of silver from the same area. This could be an ore source with discrete gold levels, potentially resulting in one batch with very low levels of gold, and another batch with around 
$6 \%$ gold. Such a wide range of gold concentrations excludes argentiferous galena or cerussite ores, thereby ruling out the Aegean and Anatolia as potential ore sources (both have gold levels generally under $1.5 \%$ and much lower Pb crustal ages). As an alternative, silver produced from some of the jarositic ores from Rio Tinto in the Iberian Pyrite belt has been found to contain $0.3 \%-16 \%$ gold, with different colours of this ore potentially reflecting very different gold levels (Gale et al. 1980), so the silver that makes up (7) could be from black or grey jarositic ore from Spain $(\sim 0.3 \mathrm{wt} \% \mathrm{Au})$, while the silver lying on the intersecting lines which converge at (5) could have derived from yellow jarosite (up to $16 \% \mathrm{Au}$ ).

Nonetheless, the early chronology of the Early Iron Age hoards makes another possibility plausible. The density map at (7) shows the distribution of crustal ages and $\mathrm{Au} / \mathrm{Ag}$ for silver artefacts from indigenous Bronze Age contexts in Iberia, widely thought to derive from native silver (calculated from LIA and compositional data from Comendador Rey et al. 2014, Bartelheim et al. 2012, Murillo-Barroso et al. 2015, Murillo-Barroso 2013). It can be seen that the density map and the cluster at (7) are very close both in terms of $\mathrm{Pb}$ crustal age and $\mathrm{Au} / \mathrm{Ag}$. This suggests that some of the silver in the hoards of Ein Hofez, Tel Keisan, Tel Dor and Eshtemoa could have derived from the same native silver sources exploited by the indigenous Bronze Age inhabitants of Iberia.

This proposition is supported in three ways:

- Unlike argentiferous jarositic ores, which were smelted and cupellated, the processing of native silver does not require the addition of lead (Murillo-Barroso et al. 2015). Consequently, a narrow spread in $\mathrm{Pb}$ crustal age is anticipated for silver derived from native silver, whereas a much wider spread would result from cupellated silver, especially if exogenous lead from a different region was used as the silver collector. Figure 9 shows the relatively narrow range of Bronze Age silver compared to silver from the Orientalising period (eighth-sixth centuries BC) in Iberia (i.e. when cupellation was used to extract silver from the argentiferous lead). Clearly, in terms of crustal age, a native silver source for the cluster at (7) is a more likely interpretation.

- Native silver tends to have lower levels of gold than does Orientalising silver. This seems to be supported by the 55 out of 58 Bronze Age silver samples from Iberia in Fig. 7 with a mean $\mathrm{Au} / \mathrm{Ag} \times 100$ of 0.08 (range: 0-0.37 $\mathrm{Au} / \mathrm{Ag} \times 100$ ), compared to Orientalising silver which is an order of magnitude higher ( $\mathrm{Au} /$ $\mathrm{Ag} \times 100=0.83$; range: $0-8.22 \mathrm{Au} / \mathrm{Ag} \times 100$ ). Three silver samples, however, found in the predominantly gold Bronze Age hoard of Tesoro de Villena have been shown to have much higher gold levels $(3.6 \%, 4.7 \%$ and $25.3 \% \mathrm{Au}$ ) (Montero-Ruiz et al. 2016), possibly reflecting the fact that their chronology is later than that of the rest of the silver in the Bronze Age dataset. Nevertheless, high gold levels tend to support that (5) in Fig. 6 (above) is potentially reflective of Spanish jarosite, as this intersect is not only commensurate in terms of $\mathrm{Pb}$ crustal age with a Hercynian argentiferous ore deposit (Fig. 8, above), but also the Au levels are in the range found in jarositic ores $(0.3 \%-16 \% \mathrm{Au})$ and Orientalising silver objects $(0 \%-6.4 \% \mathrm{Au})$. 


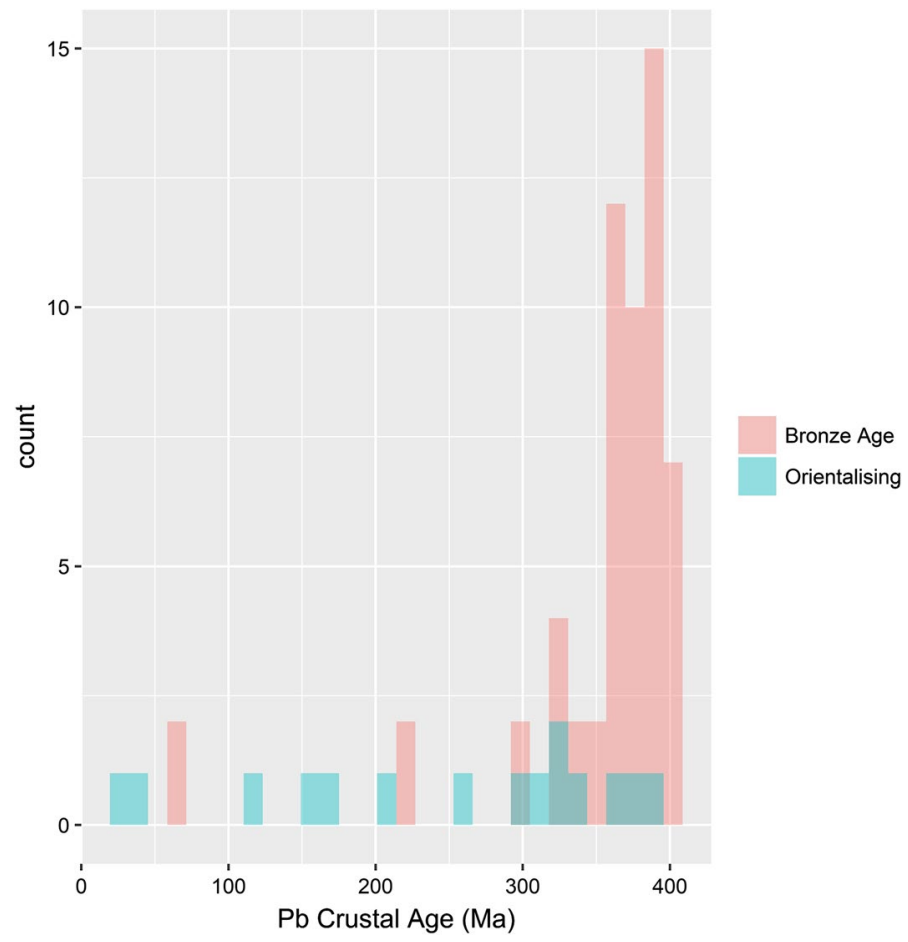

Fig. 9 Frequency histogram of the $\mathrm{Pb}$ crustal age (Ma) for Argaric and Orientalising silver (eighth-sixth centuries BC) from Iberia, showing overlapping areas, as calculated from the lead isotopes using the two-stage evolution model with parameters from Desaulty et al. (2011). LIA and compositional data for Orientalising silver from Murillo-Barroso et al. (2016). LIA and compositional data for Argaric silver from Comendador Rey et al. (2014), Bartelheim et al. (2012), Murillo-Barroso et al. (2015), MurilloBarroso (2013)

- A compositional feature that further supports the representation of both native silver and smelted silver from jarosite in the dataset is that cupellated silver often has higher levels of lead. Considering the cluster of points which make up (7) (i.e. $300 \mathrm{Ma}-410 \mathrm{Ma}$ ), it can be seen (Fig. 10) that most samples are made up of silver with low concentrations of lead (i.e. $<1 \mathrm{wt} \% \mathrm{~Pb}$ ). These include the two samples from the early hoard of Tell Keisan (late 11th century BC) and are suggestive of native silver from Iberia, that is, low lead $<0.3 \mathrm{wt} \% \mathrm{~Pb}$, low gold $<0.3$ $\mathrm{wt} \% \mathrm{Au}$ and high crustal age $400 \mathrm{Ma}$. The potentially later hoards of Eshtemoa and Ein Hofez include silver with both low and high lead contents $(<0.2 \mathrm{wt} \%-$ $2.44 \mathrm{wt} \% \mathrm{~Pb}$ ), perhaps indicating that these hoards contained both native silver and silver from jarositic ores.

It is therefore proposed that the Iberian silver that ended up in the Levantine hoards included native silver acquired directly from the Bronze Age inhabitants of the Iberian Peninsula, as well as silver mined from jarosite ores, apparently at a similar time: for example, the hoards of Tell Keisan contain silver potentially derived 


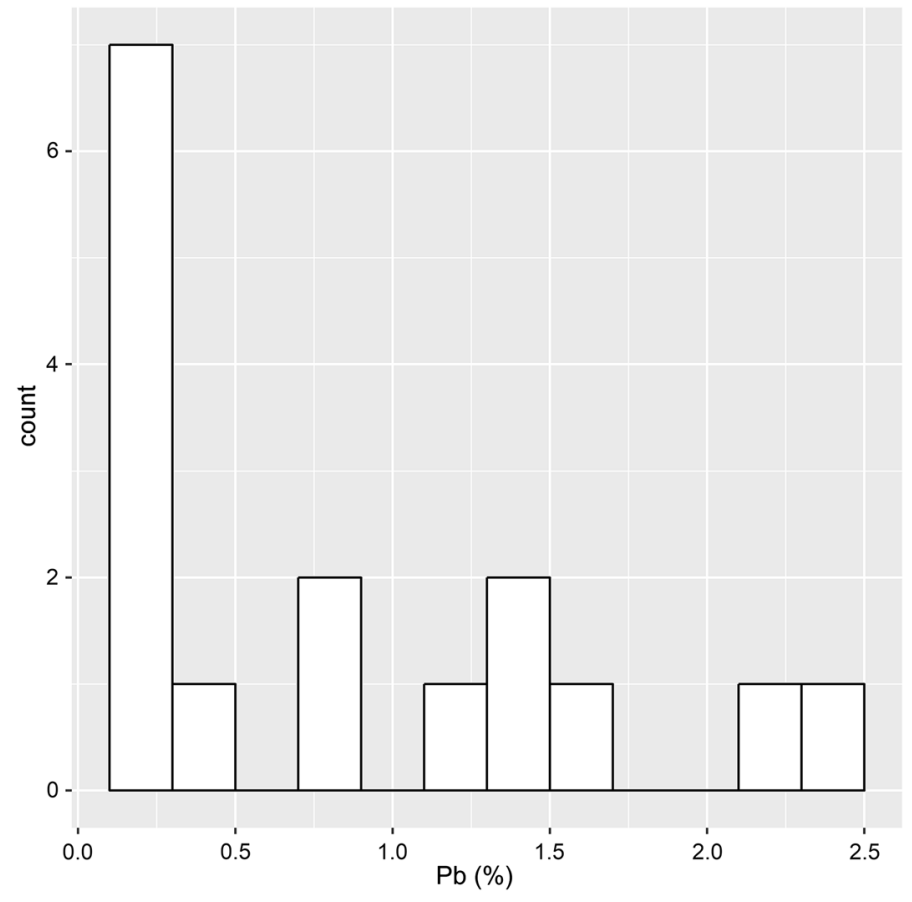

Fig. 10 Frequency histogram of the $\mathrm{Pb} \%$ for data at (7) in Fig. 6 (above) lying between $300 \mathrm{Ma}$ and $410 \mathrm{Ma}$, i.e. low gold/high crustal age silver from the hoards of Ein Hofez, Eshtemoa, Tel Dor and Tell Keisan (Oxalid 2018)

from native silver (7) and from jarosite (orange mixing line). This again supports the idea that silver from Iberia was available throughout this region from the late 11th century BC.

The red mixing line connects, albeit imperfectly, the cluster at (1) to silver deposited at Akko, with crustal ages over $600 \mathrm{Ma}$ (6). This suggests that silver from a very old ore source was available in Akko between the ninth and eighth centuries $\mathrm{BC}$. The red line appears to connect this group with the silver used at Tel el 'Ajjul (1) through silver mixtures deposited at Akko, Tel Dor, Ashkelon and Tell Keisan, some of which pre-date the Akko hoard deposition. This mixing line would therefore suggest that silver from the high crustal age ore $(>600 \mathrm{Ma})$ making the end member of this line was available when the mixtures were made in the 11th century $\mathrm{BC}$, even though some of this mixed silver was deposited at Akko much later. Such a high crustal age reflects Caledonian orogenies (Valera and Valera 2005). Silverbearing ores with high ages are not common throughout the Mediterranean, with the younger Alpine domain generally overlying the Hercynian and Caledonian basement. Figure 8 (above) shows that ores of this age are present in Iberia and Sardinia. Sardinian ores, however, are predominantly lead-zinc-silver galenas, which would result generally in objects with $<0.1 \% \mathrm{Au}$ (De Caro et al. 2013). Furthermore, no silver objects certainly dated to the Nuragic age have been discovered in Sardinia (Artzeni et al. 2005). Therefore, it seems more probable that the cluster at 
(6) reflects silver-bearing jarositic ores in Iberia with crustal ages of over $600 \mathrm{Ma}$ that were mined in the Early Iron Age. Again, like the blue and orange mixing lines, this would reflect the idea that silver from argentiferous jarositic ores was available for mixing from the 11th century BC. Essentially, this would imply that jarosite was smelted and silver was refined through cupellation in Iberia at least from the late 11 th century BC.

Point (7) is made up of silver from Ein Hofez, Eshtemoa, Tel Dor, and Tell Keisan and (1) comprises silver from Tel el 'Ajjul and Tell Keisan. Although close to the detection limits of the ED-XRF measurements, a black mixing line can be drawn through silver deposited in hoards at these locations as well as at Ashkelon. The end members suggest silver derived from ores at Taurus (1) and silver from Iberia (7), either native or derived from gold-poor jarositic ores. The line is similar to the red mixing line in Fig. 4 for the Miqne-Ekron and Ein Gedi hoards of the seventh century BC, and may thus point to some continuity in the sourcing of silver from the Early Iron Age.

In summary, the plots (Figs. 4, 6, above) suggest that four ore sources of silver are represented (and widely mixed) in the dataset of 150 samples from Levantine hoards, with crustal ages of about $-80 \mathrm{Ma}, 0 \mathrm{Ma}, 380 \mathrm{Ma}$ and $620 \mathrm{Ma}$. The first is from an unknown source, the second is consistent with ores from the Taurus mountains of Anatolia in the early hoards and Laurion in the later hoards, the third is consistent with ores from Iberia and the fourth with ores from either Sardinia or Iberia. In most cases, different gold levels can be explained by silver being mixed (probably unintentionally) with gold. This explanation would seem appropriate for all silver lying on the mixing lines. The silver with a $\mathrm{Pb}$ crustal age of $620 \mathrm{Ma}$ could reflect a still unknown silver-bearing jarosite from Iberia rather than an argentiferous galena ore from Sardinia with added gold. Silver exhibiting crustal ages around $380 \mathrm{Ma}$ was probably derived from silver from different Spanish sources: low gold, low lead and crustal ages commensurate with Iberia indicate a native silver source (as used by the indigenous Late Bronze Age/Early Iron Age inhabitants of Iberia), whereas higher levels of gold and lead are potentially the consequence of smelting jarosite ores. Both types of silver appear to have ended up in the Early Iron Age hoards, which suggests that cupellation was a process used to acquire silver in Iberia from at least the late 11 th century BC.

\section{Discussion}

The combination of estimated crustal ages based on lead isotope analyses and gold concentrations in ancient silver makes it possible to identify groups of objects that are likely to derive from the same source or batch, and allows the identification of mixing lines between groups. Considering the mixing lines, it becomes clear that in order to explain the relatively high gold level of some silver found in the southern Levant there is no need for gold to have come from some ancient, now exhausted, mine in the Eastern Desert of Egypt (Lucas 1928; Shalev et al. 2014). In fact, a silver mount from a jar from a site in Predynastic Egypt, despite having high levels of gold $(\mathrm{Au}=33.74 \%)($ Gale and Stos-Gale 1981b; Stos-Gale and Gale 1981) has a crustal 
age which is too low (194 Ma) to be consistent with the silver in Fig. 5 (above) at (5) and (7). Lead objects from Egypt show similar crustal ages, thus making it unlikely that Egyptian metal is in any way prevalent in the silver hoards discussed here.

A linear mixing line suggests that two components-batches of silver with differing crustal ages and/or gold concentrations-were mixed together. By this rationale, any silver found on a linear mixing line must have been deposited after both component batches were available in the region. Furthermore, when clusters or intersections are found as the end members of these mixing lines (i.e. groups of silver with similar crustal ages and gold levels which were subsequently deposited in hoards as received or mixed), they potentially delineate where each batch of silver was from. For example, the fact that the cluster at low crustal ages and low gold levels (1) is predominantly from silver deposited at Tell el 'Ajjul, suggests that this type of silver was common at this location. This type of silver is probably from silver mines in the Taurus mountains, which suggests that the area around Tell el Ajuul (which became part of Philistia) had some kind of connection with this area in the 12th-11th centuries BC. Similarly, the silver responsible for the cluster at Tell Keisan, Ein Hofez and Eshtemoa (7), suggests that these locations had some kind of connection with Iberia from the late 11 th century BC.

The mixtures of silver between (1) and (7) were predominantly deposited in hoards at Ein Hofez, but not Tell el 'Ajjul. This is not surprising. Tell el 'Ajjul was a Canaanite site that 'ceased to function' in the Late Bronze Age (Dessel 1997, p. 38), although it was still occupied during the Early Iron Age (Albright 1938; Fischer and Sadaq 2006, pp. 1565-1566). Since the hoard is probably from the Late Bronze Age, this suggests that any mixing of this type of silver occurred after this hoard was deposited. In other words, Iberian silver may not have been available at the time when the Tell el 'Ajjul hoard was deposited, although it was clearly available in the Early Iron Age as the mixing line between (1) and (7) demonstrates, that is, silver with the same signature as silver hoarded at Tell el 'Ajjul was mixed with Iberian silver and found in the hoards at Ashkelon, Eshtemoa and Ein Hofez.

The nature of the connections between production and consumption centres is difficult to interpret, and more work will be needed to contextualise our findings and discuss their significance. Nonetheless, it is interesting to note that Ein Hofez and Tell Keisan are in the north, while Tell el 'Ajjul is in the south (in the general area of Philistia). This patterning could indicate that silver from different ore sources was supplied to these different areas- that Taurus supplied the south and Iberia supplied the north. This interpretation appears to be supported by the fact that only one piece of 'unmixed' silver from the cluster at (1) ended up in the north, in a hoard at Tell Keisan. Such a north-south scenario is difficult to pursue, however: more hoards have been discovered in the north, and any conclusions drawn along these lines would be strongly affected by sampling bias. Furthermore, a more historical approach might perhaps explore the differences between those areas under the influence of the Philistines (i.e. Gaza, Ashkelon, Ashdod, Ekron and Gat on the eastern plain) and those outside it. Nevertheless, the only Early Iron Age Philistine city where a silver hoard has been discovered is Ashkelon.

Another point deserving further discussion is the possible impact of Laurion on silver recovered in the Levant. It was noted above that Miqne-Ekron, which was in 
Philistine territory, used silver from Laurion in the seventh century BC. The silver deposited in the earlier Tell el 'Ajjul hoard, however, appears to derive from Anatolian ores. Unfortunately, as shown in Figs. 5 and 7 above, calculated crustal ages cannot discriminate conclusively between those two sources (Laurion and Taurus), and the traditional LIA plots (Fig. 7) are also open to interpretation. Thompson (2009 citing Coldstream 1977, p. 70) suggests that the infrequency of Aegean silver in the Early Iron Age hoards from Cis-Jordan corresponds to the lack of evidence for mining activities at Laurion and nearby Thorikos between the Mycenean period and the mid ninth century, and that any silver in the Early Iron Age hoards which can be shown to derive from Laurion is most likely residual from trade that took place during the Late Bronze Age, rather than an indication of continuing trade with the Aegean after c. 1200 BC. Our data suggests that the Taurus mountains in Anatolia (Fig. 7) are the more likely origin of the silver for the predominant component of the Early Iron Age mixing lines (i.e. cluster 1 in Fig. 6), while Laurion supplied the silver which was subsequently mixed in the later hoards (Figs. 4, 5).

While the identification of the source of silver in the clusters is important, it is the relatively linear mixing lines which provide the rationale behind the plots, as they reveal trends that would not be easily discernible with more common approaches to the data. Inevitably, some of our suggested mixing lines are more obvious than others, and there are outliers that may derive from analytical errors and/or silver that was mixed from more than two sources. However, the fact that mixtures are found in all hoards, including that at Philistine Ashkelon, suggests that all sites had access to the different types of silver which made up these mixtures, probably through the port cities of Ashkelon, Tel Dor and Akko. This could imply some form of mercantile trade in silver.

Vertical mixing lines are also evident on the plots, representing variable $\mathrm{Au} /$ Ag ratios but relatively constant crustal ages (Figs. 4, 6, above). In Fig. 6 these are shown as the vertical dashed lines between (2) and (3) and (1) through (4). Whereas the blue dashed line probably reflects the mixing and recycling of silver from Taurus ores (with various levels of gold), the red dashed line suggests that a further source was exploited in the Early Iron Age, potentially Thera, Kythnos or Cyprus. Most of the silver on this mixing line ended up in the hoards of Tel Dor, which suggests not only that mixing was conducted there but also that it may have had a special relationship with the suppliers of silver from this particular ore source. The interesting issue here is that silver of similar crustal ages was mixed together, increasing the gold concentration and thereby resulting in a vertical mixing line. Such a scenario is much more likely if finished objects were being melted down, for example to make ingots to trade or hoard. The hoard at Miqne-Ekron (Fig. 4, above) may be an example of this, where the deposition site of the mixtures is the same as the source component, with mixing potentially conducted just prior to the Neo-Babylonian attack in 604 BC.

Where find sites are different from one of the source components, a vertical mixing could be interpreted as the melting down of silver and the mixing of booty from conflict, that is, if silver was secured in the form of objects with styles not favoured by those who acquired them. In this particular case (Fig. 6 points 2 and 3 and 1 through 4 ), this interpretation is supported to some extent by the fact that no 
silver from the mixtures (either the blue or red dashed mixing lines) was found at the Philistine city of Ashkelon. This absence could suggest that the silver in these mixtures was acquired and melted down from objects deriving from Philistia (i.e. objects made of silver with an initially low gold concentration but with gold parts) to inadvertently produce alloys with the same $\mathrm{Pb}$ crustal age as the initial silver, namely $0 \mathrm{Ma}$ (1) and - $80 \mathrm{Ma}$ (2), but with $\mathrm{Au} / \mathrm{Ag}$ concentrations of several percent. In other words, silver of this composition, which was not available at Ashkelon, was generated from melting down silver objects at Tel Dor that had been obtained from Philistia and subsequently deposited in hoards at Tel Dor, Bet Shean and Akko. That this silver ( $3 \mathrm{and} /$ or 4 ) also appears as an end member of another mixing line (orange line) suggests that a large amount of silver of this unusual composition was available at Tel Dor, and subsequently mixed with Iberian silver with even higher gold levels, ending up in hoards in non-Philistine areas, particularly at the commercial centre of Shechem. It is probable that this commercial centre, due to its position in the middle of vital trade routes through the region from the Middle Bronze Age (Wood 1997), disseminated silver back throughout the northern region. Furthermore, the fact that some of this silver ended up in hoards at Bet Shean and Tell Keisan supports the suggestion that silver from this mixing line, and thereby Iberian silver, was available during the 11 th century $\mathrm{BC}$.

\section{Phoenicians}

The question of who shipped silver to the east from Iberia, of course, is an entirely different issue. Iron Age Phoenician overseas contacts, demonstrated mainly in Cyprus, but also including a tenth century BC pre-colonial presence at Huelva in southeastern Spain (Gonzalez de Canales et al. 2004), suggest potential connections between the Phoenicians and Tel Dor (Gilboa 2013), and thereby, the cities of the Carmel coast with Iberia. Furthermore, it has been speculated that the Tel Dor hoard (about $8.5 \mathrm{~kg}$ silver in a clay jar, resembling small coins and stored in linen bags) belonged to a Phoenician merchant (Stern 1998). A container found at the Andalusian site of Purullena, comparable to pithoi found on the Uluburun (14th c. BC), Cape Gelidonya and Point Iria (13th c. BC) shipwrecks, could suggest that traders from the eastern Mediterranean had been frequenting the Iberian shores for several centuries. Moreover, wheel-made sherds of Mycenaean origin at local Cogotas I sites in Montoro (i.e. 13th-10th centuries BC) were potentially transported by Cypriots (Ruiz-Galvez 2014, pp. 196-214). However, isolated finds are probably not the best way to decouple foreign objects from foreign agents (Russell and Knapp 2017). By contrast, technological innovations may provide more convincing evidence of sustained contact, as they may require direct knowledge transmission. It is not the intention of this paper to get into the generally binary debates regarding the socioeconomic and cultural impact of the east on the west at the end of the Late Bronze Age. However, it is worth noting that the adoption in the western Mediterranean of a complex technology for metallurgical exploitation (rather than just trading) prompted by foreign contacts would appear to challenge the minimalist view (e.g. Russell and Knapp 2017) and support the proposal of more substantial networks 
stimulated by the movement of metals (Sherratt and Sherratt 1991, pp. 351-386; Lo Schiavo 1990). This is irrespective of who were the conveyers of the silver.

With regard to the Phoenicians, a fundamental question would be whether they knew that there was silver in the west prior to their well-attested presence at the coastal sites of Iberia by the last quarter of the 9th century BC (according to carbon dating) (Ruiz-Galvez 2014, pp. 196-214) and whether the presence of native and cupellated silver in the Early Iron Age hoards of the southern Levant can shed some light on this question.

The breakdown of the palatial system around $1200 \mathrm{BC}$ discharged not only merchants but also skilled craftsmen (Zaccagnini 1983), hence the first explorations of the western Mediterranean may have been associated not only with trade but also with technology. Both the Bronze Age Berzocana and Villena hoards in Iberia suggest technology with Cypriot or Canaanite/Levantine origins. The Berzocana hoard shows connections with the Cypriot-Levantine area, with a bronze bowl of the Cypriot-Canaanite type (Ruiz-Galvez 2014, pp. 196-214, citing Torres 2012), made using the lost-wax technique, bearing close resemblance to bowls from the Jatt hoard in Israel and bowls at Megiddo, both from around the end of the 11th century (Artzy 2006). These hoards support the view that Megiddo was a Canaanite city actively involved in maritime trade with both Phoenicians and Cypriots (Artzy 2006). Atlantic objects found in graves in Cyprus (Karageorghis and Lo Schiavo 1989) tend to support this position. The Villena hoard contains exotic elements such as a nail (unknown in the Bronze Age, having been developed in Cyprus c. 1200 $\mathrm{BC}$ ) and a gold-inlaid iron object (with iron being rare in Iberia during the Late Bronze Age) (Ruiz-Galvez 2014, pp. 196-214). In terms of knowledge transmission and therefore sustained contact, the very presence of iron metallurgy more broadly has been highlighted as a technological innovation for this period, with the earliest artefacts, including tools, dating to the 11th century BC (Vilaça 2006, 2013). Further indications of sustained interaction between the eastern Mediterranean and Iberia is found at Monte de Ramada 1 (southern Portugal): here, a tenth century $\mathrm{BC}$ assemblage includes unusual bronze alloys as well as glass, faience, and ostrich shell beads, which have been interpreted as testifying to an archaic trade with the Mediterranean region before the establishment of the first Phoenician colonies on the southern Iberian coast (Valério et al. 2017).

The growing body of evidence for Cypriot or Canaanite/Levantine presence in Iberia suggests that the Phoenicians might not have been the protagonists in the first exchanges, and that when the Phoenicians arrived in the west, they already knew exactly where they were sailing to and what they were looking for (Ruiz-Galvez 2014, pp. 196-214). In fact, just as it may be argued that Cypriot or Canaanite/ Levantine traders and craftspeople were searching for new markets and expanding their networks westward (Almagro-Gorbea 2001), the indigenous inhabitants of Iberia, in turn, may have seen in this an opportunity to export products and resources towards the Mediterranean, to supplement their Atlantic trade routes. This opportunity could be reflected in the presence of Iberian native silver found in the early Iron Age hoards of the southern Levant.

This is perhaps the point where the Phoenicians reveal themselves. The presence of silver in Iberia, to which they were alerted by the arrival of native silver in the 
Levant in the 11th century $\mathrm{BC}$, could have provided the impetus for risky and costly ventures west, with existing commercial dealings paving the way (e.g. information regarding ports of call, routes, resources and local populations). Since argentiferous jarosite ores are not located in the triangular area of Huelva, the Guadalquivir valley and Cadiz, but farther inland, it is possible that the coastal indigenous groups played a mediating role for the Phoenicians with groups in the interior of the country (Celestino and Ruiz-Lopez 2016, p. 152). In other words, the Phoenicians, bringing their knowledge of refining silver through cupellation, could have negotiated their way to the ore deposits using the information they had acquired before they set sail. This is in agreement with Hunt's (2003) field research which highlighted the absence of evidence of cupellation prior to the arrival of the Phoenicians. However, the new evidence presented here would push the dates further back.

According to current archaeological evidence, the Phoenicians first arrived at the end of the tenth century $\mathrm{BC}$ to Huelva, and to Cadiz a century later (Celestino and Ruiz-Lopez 2016, p. 303). However, some of the silver found in the southern Levantine hoards dated back to the 11th century BC appears to have been mixed with silver from jarosite sources, which would have required cupellation. As noted by Broodbank (2013, p. 485), the Phoenicians were 'as much the creations as the creators of the evolving culture and networks associated with them'. As such, it may be appropriate to consider them a composite of the aforementioned Cypriot and Canaanite/Levantine traders. This is especially pertinent before the 11th century $\mathrm{BC}$, prior to time of the common language and script for which the Phoenicians are best known, when distinctions are more difficult to delineate (e.g. Bell 2009). The traders who travelled to Iberia and transmitted the lost-wax casting technique, iron metallurgy and other technologies to the indigenous population in the 11th century $\mathrm{BC}$, having witnessed first-hand the wealth around Huelva, could have decided to exploit the natural resources by introducing cupellation. Irrespective of the label we use for these traders, if this proposal is correct, then there must be earlier evidence of cupellation in the archaeological record in Iberia that has yet to be discovered or identified.

Overall this hypothesis implies that the first conveyors of silver to the southern Levant from the western Mediterranean were not miners but traders who had acquired silver directly from the indigenous Bronze Age inhabitants of Iberia, who supplied native silver (with high crustal ages, low lead and low gold levels) perhaps in return for prestige gifts, new technology and access to the Mediterranean trade routes. Considering that the transmission of wheel-made pottery is generally accepted to be a process requiring close contact between master and apprentice, its presence in Iberia, alongside other technology (the lost-wax technique, the use of nails, as well as iron objects) supports the view that eastern Mediterranean craftsmen permanently, or perhaps seasonally, installed themselves among the native population (Ruiz-Galvez 2014, pp. 196-214). It is perhaps these contacts that allowed the Phoenicians (or perhaps a Cypriot-Canaanite/Levantine composite which became the Phoenicians), along with the method of cupellation, to exploit silver ore resources that had been previously inaccessible to the native inhabitants almost at the same time as the arrival of native silver in the Levant. If this is correct, it would also confer validity, at least in terms of chronology, on the hypothesis of Phoenicians 
carrying precious metals from Tarshish to the southern Levant at the time of Solomon (c. tenth c. BC) (Beitzel 2010; Thompson and Skaggs 2013), potentially building on existing trade relations with the Bronze Age inhabitants of Iberia from the 11 th century $\mathrm{BC}$.

\section{Conclusions}

Compositional and lead isotope data from silver found in the Iron Age hoards of the southern Levant have been combined to refine hypotheses about the ore sources and clarify evidence of mixing. Mixing lines suggest that the Late Iron Age silver found at Miqne-Ekron and Ein Gedi was sourced from the Laurion and a much older ore with a signature commensurate with jarosite ores in Iberia. The Laurion ores have a signature commensurate with argentiferous galena. Similarly, Early Iron Age silver recovered from Akko, Ashkelon, Bet Shean, Ein Hofez, Tel Dor, Tell el 'Ajjul, Tell Keisan, Shechem and Eshtemoa can be sourced to the Taurus mountains in southern Anatolia, Iberia and possibly Sardinia. Furthermore, the mixing lines and compositional analyses indicate that two types of Iberian silver were used in the Early Iron Age hoards: native silver and silver from jarositic ores. This suggests that early contact between eastern Mediterranean peoples and the Iberian Peninsula involved the negotiation of silver from the indigenous Bronze Age inhabitants of Iberia, but also the mining of jarosite ores which required cupellation, potentially as early as the 11th century BC. The rationale behind the mixing plots, however, is that compositional and isotopic data can be presented in a way which situates mixing events in time and space. In effect, silver objects deriving from mixtures of silver from different sources, which have been deposited at different locations and at different times, can be used to identify episodes of mixing. The patterns which emerge from analysing these mixing events, such as vertical mixing lines which potentially reflect social-political contexts when it became judicious to melt down silver objects rapidly without removing gold parts, essentially provide a further approach to investigate the movement of artefacts which were recycled and reused prior to deposition in the archaeological record.

OpenAccess This article is distributed under the terms of the Creative Commons Attribution 4.0 International License (http://creativecommons.org/licenses/by/4.0/), which permits unrestricted use, distribution, and reproduction in any medium, provided you give appropriate credit to the original author(s) and the source, provide a link to the Creative Commons license, and indicate if changes were made.

\section{References}

Albarède, F., Desaulty, A.-M., \& Blichert-Toft, J. (2012). A geological perspective on the use of Pb isotopes in archaeometry. Archaeometry, 54, 853-867.

Albarède, F., \& Juteau, M. (1984). Unscrambling the lead model ages. Geochimica Cosmochimica Acta, 48, 207-212.

Albright, W. F. (1938). The chronology of a south Palestinian city, Tell el 'Ajjul. American Journal of Semitic Languages and Literature, 55(4), 337-359. 
Almagro-Gorbea, M. (2001). Cyprus, Phoenicia and Iberia: From 'precolonization' to colonization in the 'far west'. In L. Bonfante \& V. Karageorghis (Eds.), Italy and Cyprus in antiquity 1500-450 BC (pp. 239-270). Nicosia: Costakis and Leto Severis Foundation.

Artzeni, C., Massidda, L., \& Sanna, U. (2005). Part III: Archaeometric data. In F. L. Schiavo, A. Guimlia-Mair, U. Sanna, \& R. Valera (Eds.), Archaeometallurgy in Sardinia: From the origins to the beginning of the Early Iron Age (pp. 113-185). Montagnac: Editions Monique Mergoil.

Artzy, M. (2006). The Jatt metal hoard in Northern Canaanite/Phoenician and Cypriot context. Cuadernos de Arqueologia Mediterranean 14 Barcelona: Publicaciones del Laboratorio de Arqueologia de la Universidad Pompeu Fabra de Barcelona.

Aubet, M. E. (1993). The Phoenicians and the west: Politics, colonies and trade. Cambridge: Cambridge University Press.

Bartelheim, M., Contreras Cortes, F., Moreno Onorato, A., Murillo-Barroso, M., \& Pernicka, E. (2012). The silver production of the South Iberian El Agar culture: A first look at production and distribution. Trabajos de Prehistoria, 69, 293-309.

Beitzel, B. J. (2010). Was there a joint nautical venture on the Mediterranean sea by Tyrian Phoenicians and early Israelites? Bulletin of the American Schools of Oriental Research, 360, 37-66.

Bell, C. (2009). Continuity and change: The divergent destinies of LBA ports in Syria and Lebanon across the LBA/Iron Age Transition. In C. Bachhuber \& G. Roberts (Eds.), Forces of transformation: The end of the Bronze Age in the Mediterranean. Oxford: Oxbow.

Broodbank, C. (2013). The making of the Middle Sea: A history of the Mediterranean from the beginning to the emergence of the classical world. London: Thames \& Hudson.

Butcher, K., \& Ponting, M. (2014). The metallurgy of Roman silver coinage: From the reform of Nero to the reform of Trajan. Cambridge: Cambridge University Press.

Celestino, S., \& Ruiz-Lopez, C. (2016). Tartessos and the Phoenicians in Iberia. Oxford: Oxford University Press.

Coldstream, J. M. (1977). Geometric Greece. London: Routledge.

Comendador Rey, B., Millos, J., \& Alvarez-Iglesias, P. (2014). Provenance of the prehistoric silver set of Antas de Ulla north-western Iberia, using lead stable isotope ratios. In H. H. Meller, R. Risch, \& E. Pernicka (Eds.), Metals of power: Early gold and silver (Vol. 11, 1). Tagungen des Landesmuseums für Vorgeschichte Halle. Halle: Landesmuseum für Vorgeschichte.

De Caro, T., Parisi, E. I., Faraldi, F., \& Caschera, D. (2013). Ancient silver extraction in the Montevecchio mine basin (Sardinia, Italy): Micro-chemical study of pyrometallurgical materials. Applied Physics A, 113, 945-957.

Desaulty, A.-M., Telouk, P., Albalat, E., \& Albarède, F. (2011). Isotopic Ag-Cu-Pb record of silver circulation through 16th-18th century Spain. PNAS, 108, 9002-9007.

Dessel, J. P. (1997). Ajjul, Tell el-. In E. M. Meyers (Ed.), The Oxford encyclopedia of archaeology in the Near East (Vol. 1). Oxford: Oxford University Press.

Eshel, T. M., Yahalom-Mack, N., Shalev, S., Tirosh, O., Erel, Y., \& Gilboa, A. (2018). Four Iron Age hoards from southern Phoenicia: From bundles to hacksilber. BASOR, 379, 197-228.

Fischer, P. M., \& Sadaq, M. (2006). 'Ajjul, Tell el-. In E. Stern (Ed.), New encyclopedia of archaeological excavations in the Holy Land (Vol. 5). Jerusalem: Israel Exploration Society.

Frankenstein, S. (1979). The Phoenicians in the far west: A function of Neo-Assyrian imperialism. In M. T. Larsen (Ed.), Power and propaganda (pp. 263-294). Copenhagen: Akademisk Forlag.

Gale, N. H., Gentner, W., \& Wagner, G. A. (1980). Mineralogical and geographical silver sources of archaic Greek coinage. In D. M. Metcalf \& W. A. Oddy (Eds.), Metallurgy in numismatics I. London: The Royal Numismatics Society.

Gale, N. H., \& Stos-Gale, Z. A. (1981a). Cycladic lead and silver metallurgy. Annual of the British School in Athens, 76, 169-224.

Gale, N. H., \& Stos-Gale, Z. A. (1981b). Ancient Egyptian silver. Journal of Egyptian Archaeology, 67, $103-115$.

Gale, N. H., Stos-Gale, Z. A., \& Davis, J. L. (1984). The provenance of lead used at Ayria Irini, Keos. Hesperia, 53, 389-406.

Gilboa, A. (2013). A propos Huelva: A reassessment of 'Early' Phoenicians in the west. In J. M. Campos \& J. Alvar (Eds.), Tarteso: El emporio del metal (pp. 311-335). Córdoba: Almuzara.

Gitin, S. (1995). Tel Miqne-Ekron in the seventh century BCE: The impact of economic innovation and foreign cultural influences on a Neo-Assyrian vassal city-state. In S. Gitin (Ed.), Recent excavations in Israel: A view to the west. Colloquia and conference papers No. 1 (pp. 61-71). Dubuque: Archaeological Institute of America. 
Gitin, S., \& Golani, A. (2001). The Tel Miqne-Ekron silver hoards: The Assyrian and Phoenician connections. In M. S. Balmuth (Ed.), Hacksilber to coinage: New insights into monetary history of the Near East and Greece. New York: American Numismatics Society.

Gitler, H., Ponting, M., \& Tal, O. (2009). Athenian Tetradrachms from Tel Mikhal (Israel): A metallurgical perspective. American Journal of Numismatics, 21, 29-49.

Golani, A. (2009). The development, significance and function of jewelry and the evolution of the jeweler's craft in the Land of Israel during Iron Age II. Unpublished Ph.D. dissertation, Tel Aviv University, Tel Aviv.

Gonzalez de Canales, F., Serrano, I., \& Llompart, J. (2004). El emporio fenicio precolonial de Huelva (ca. 900-770 a.C.). Madrid: Biblioteca Nueva.

Hunt, M. (2003) Prehistoric mining and metallurgy in the south west Iberian peninsula. International Series: British Archaeological Reports, S1188, Oxford: Archaeopress.

Jones, R. E., Levi, S. T., Bettelli, M., \& Vagnetti, L. (2014). Italo-Mycenaean pottery: The archaeological and archaeometric dimensions (Incunabula Graeca 103). Rome: Consiglio Nazionale delle Ricerche.

Karageorghis, V., \& Lo Schiavo, F. (1989). A west Mediteranean obelos from Amathus. Revista di Studi Fenici, 17, 15-29.

King, P. J., \& Stager, L. E. (2001). Life in Biblical Israel. Louisville: Westminster John Knox Press.

Kletter, R., \& Brand, E. (1998). A new look at the Iron Age silver hoard from Eshtemoa. Zeitschrift des Deutschen Palästina-Vereins, 114(2), 139-154.

Lo Schiavo, F. (1990). Copper oxide and plano-convex ingots in Sardinia. In L. Lo Schiavo, R. Maddin, J. Merkel, J. D. Muhly, \& T. Stech (Eds.), Metallographic and statistical analyses of copper ingots from Sardinia (pp. 15-40). Ozieri, Sardinia: Ministero per I Beni Culturali e Ambientali, Soprintendenza ai Beni Archeologici per le Province de Sassari e Nuoro, Quaderni 17, Torchietto.

Lucas, A. (1928). Silver in ancient times. Journal of Egyptian Archaeology, 14, 313-319.

Mazar, B. (1993). Ein-Gedi. In E. Stern (Ed.), The new encyclopedia of archaeological excavations in the Holy Land 2 (pp. 399-405). Jerusalem: Israel Exploration Society.

Montero-Ruiz, I., Murillo-Barroso, M., \& Rovira Llorens, S. (2016). Objetos olvidados: Las botellas de plata del Tesoro de Villena dentro del contexto de la plata prehistórica. Biliyana, 1, 72-81.

Murillo-Barroso, M. (2013). Producción y consumo de plata en la península Ibérica: Un análisis comparativo entre la sociedad Argárica y los primeros asentamientos orientalizantes. Ph.D. thesis, Universidad de Granada, Granada.

Murillo-Barroso, M., Montero-Ruiz, I., \& Aranda Jiménez, G. (2015). An insight into the organisation of metal production in the Argaric society. Journal of Archaeological Science: Reports, 2, 141-155.

Murillo-Barroso, M., Montero-Ruiz, I., Rafel, N., Hunt-Ortiz, M. A., \& Armada, X.-L. (2016). The macro-regional scale of silver production in Iberia during the First millennium BCE in the context of Mediterranean contacts. Oxford Journal of Archaeology, 35, 75-100.

Oxalid. http://oxalid.arch.ox.ac.uk/default.html. Accessed November 27, 2018.

Pernicka, E. (1990). Gewinnung und Verbreitung der Metalle in prähistorischer Zeit. Jahrb. Röm.-Germ. Zentralmus, 37, 21-129.

Pomiès, C., Cocherie, A., Guerrot, C., Marcoux, E., \& Lancelot, J. (1998). Assessment of the precision and accuracy of lead-isotope ratios measured by TIMS for geochemical applications: Example of massive sulphide deposits (Rio Tinto, Spain). Chemical Geology, 144, 137-149. https://doi. org/10.1016/S0009-2541(97)00127-7.

Porten, B. (1981). The identity of King Adon. Biblical Archaeologist, 44, 36-52.

Postgate, J. N. (1973). The Governor's Palace archive. London: British School of Archaeology in Iraq.

Postgate, J. N. (1979). The economic structure of the Assyrian Empire. In M. T. Larsen (Ed.), Power and propaganda (pp. 193-222). Copenhagen: Akademisk Forlag.

Rehren, T., Hess, K., \& Philip, G. (1996). Auriferous silver in western Asia: Ore or alloy? JHMS, 30, $1-10$.

Ruiz-Galvez, M. (2014). Before 'The gates of Tartessos': Indigenous knowledge and exchange networks in the Late Bronze Age far west. In A. B. Knapp \& P. van Dommelen (Eds.), The Cambridge prehistory of the Bronze and Iron Age Mediterranean. Cambridge: Cambridge University Press.

Russell, A., \& Knapp, A. B. (2017). Sardinia and Cyprus: An alternative view on Cypriotes in the central Mediterranean. Papers of the British School at Rome, 85, 1-35.

Shalev, S., Shechtman, D., \& Shilstein, S. (2014). A study of the composition and microstructure of silver hoards from Tel Beth-Shean, Tel Dor, and Tel Miqne, Israel. Archaeological and Anthropological Sciences, 6, 221-225. 
Sherratt, A. G., \& Sherratt, S. (1991). From luxuries to commodities: The nature of the Mediterranean Bronze Age trading systems. In N. H. Gale (Ed.), Bronze Age trade in the Mediterranean: Papers presented at the conference held at Rewley House, Oxford, in December 1989. Studies in Mediterranean Archaeology (Vol. 90, pp. 351-386). Jonsered: P. Astroms Forlag.

Stacy, J. S., \& Kramers, J. D. (1975). Approximation of terrestrial lead isotope evolution by a two-stage model. Earth and Planetary Science Letters, 26, 207-221.

Stern, E. (1998). Buried treasure: The silver hoard from Dor. Biblical Archaeology Review, 24, 46-51.

Stos-Gale, Z. A., \& Gale, N. H. (1981). Sources of galena, lead and silver in predynastic Egypt. In Revue d'Archéométrie, 1, 1981. Actes du XX $X^{e}$ symposium international d'archéométrie, Paris 26-29 mars 1980 (Vol. III, pp. 285-296).

Stos-Gale, Z. A., Gale, N. H., Houghton, J., \& Speakman, R. (1995). Lead isotope data from the Isotrace Laboratory, Oxford: Archaeometry data base 1, ores from the western Mediterranean. Archaeometry, 37, 407-415. https://doi.org/10.1111/j.1475-4754.1995.tb00753.x.

Thompson, C. (2003). Sealed silver in Iron Age Cisjordan and the 'invention' of coinage. Oxford Journal of Archaeology, 22, 67-107.

Thompson, C. (2007). Silver in the Age of Iron and the orientalizing economies of Archaic Greece. Ph.D. dissertation, University of California, Los Angeles.

Thompson, C., \& Skaggs, S. (2013). King Solomon's silver? Southern Phoenician hacksilber hoards and the location of Tarshish. Internet Archaeology. https://doi.org/10.11141/ia.35.6.

Thompson, C. M. (2009). Three 20th Dynasty silver hoards from the Egyptian garrison. In N. PanitzCohen \& A. Mazar (Eds.), Excavations at Tel Beth-Shean, 1989-1996, vol. III, the thirteenth-eleventh century BCE strata in areas $N$ and $S$. Jerusalem: The Hebrew University of Jerusale.

Torres, M. (2012). La precolonization en Extremadura. In J. Jimenez Avila (Ed.), Siderum Ana II: El Rio Guadiana en el Bronce Final. Merida-Badajoz 28-30 de Mayo de 2008 (Vol. 52, pp. 455-474). Anejos de Archivo Espanol de Arqueologia Merida: CSIC.

Valera, R. G., \& Valera, P. G. (2005). Outline of geology and mineral deposits of Sardinia. In F. Lo Schiavo, A. Guimlia-Mair, U. Sanna, \& R. Valera (Eds.), Archaeometallurgy in Sardinia from the origins to the beginning of the Early Iron Age (pp. 35-42). Montagnac: Éditions M. Mergoil.

Valério, P., Araújo, M. F., Soares, A. M. M., Silva, R. J. C., Baptista, L., \& Mataloto, R. (2017). Early imports in the Late Bronze Age of south-western Iberia: The Bronze ornaments of the hypogea at Monte da Ramada 1 (Southern Portugal). Archaeometry, 60, 255-268. https://doi.org/10.1111/ arcm. 12310 .

Vilaça, R. (2006). Artefactos de ferro em contextos do Bronze Final do territorio portugues: Novos contributos e reavaliacao do dados (Iron artefacts in contexts of the Late Bronze Age in the Portuguese territory). Complutum, 17, 81-101.

Vilaça, R. (2013). L'arrivée des premiers fers dans l'Occident atlantique. In L. Callegarin \& A. Gorgues (Eds.), Les transferts de technologie au premier millénaire av. J.-C. dans le sud-ouest de l'Europe (pp. 39-64). Madrid: Casa de Velázquez.

Wood, B. G. (1997). The role of Shechem in the conquest of Caanan. In D. Merling (Ed.), To understand the scriptures: Essays in Honor of William H. Shea (pp. 245-256). Berrien Springs: Institute of Archaeology.

Wood, J. R., Charlton, M. J., Murillo-Barroso, M., \& Martinón-Torres, M. (2017). Iridium to provenance ancient silver. Journal of Archaeological Science, 81, 1-12.

Yeivin, Z. (1993). Eshtemoa. In E. Stern (Ed.), The new encyclopedia of archaeological excavations in the Holy Land 2 (pp. 423-426). Jerusalem: Israel Exploration Society.

Zaccagnini, C. (1983). Patterns of mobility among ancient Near Eastern craftsmen. Journal of Near Eastern Studies, 42, 245-264.

Publisher's Note Springer Nature remains neutral with regard to jurisdictional claims in published maps and institutional affiliations. 


\section{Affiliations}

Jonathan R. Wood ${ }^{1}$ [D $\cdot$ Ignacio Montero-Ruiz ${ }^{2} \cdot$ Marcos Martinón-Torres $^{1}$

$\triangle$ Jonathan R. Wood uczljrw@ucl.ac.uk

1 Institute of Archaeology, University College London, London, UK

2 Instituto de Historia-CSIC, Madrid, Spain 